\title{
ПРЕЛИМИНАРНИ РЕЗУЛТАТИ ИСТРАЖИВАЊА ИСТОЧНЕ НЕКРОПОЛЕ РЕМЕЗИЈАНЕ 2018-2020
}

\author{
Марко А. Јанковић \\ Археолошка збирка, Филозофски факултет, Универзитет у Београду \\ Владимир Д. Михајловић \\ Одсек за историју, Филозофски факултет, Универзитет у Новом Саду \\ Александар Д. Бандовић \\ Народни музеј, Београд \\ \begin{tabular}{r|r} 
e-mail: marko.jankovic@f.bg.ac.rs & Оригинални научни рад \\
Примљено: 29. 4. 2021. & УДК: 904:726.8”652”(497.11) \\
Прихваћено: 9.6.2021. & 902.2(497.11)"2018/2020”
\end{tabular}
}

\begin{abstract}
Апстракт: Иако су случајни налази гробова са простора Источне некрополе у Белој Паланци познати већ више од једног века, прва систематска археолошка истраживања, започета су 2018. године. Закључно са 2020. годином, откривено је и документовано укупно 29 гробова. Некрополу карактеришу уобичајене гробне форме, познате са других локалитета из истог периода, али и присуство ретких гробних форми (меморије), као и веома важан налаз платформе за постављање менсе (тепsа) сигма типа, откривене у унутрашњости фунерарног објекта потковичастог облика. На основу прелиминарне анализе налаза новца и покретног археолошког материјала који је откривен као инвентар гробова, овај део некрополе се може датовати у 4. век. На простору Источне некрополе констатован је и гвозденодопски културни слој, оштећен приликом укопавања гробова. До сада је истражена укупна површина од око $183 \mathrm{M}^{2}$, а претпоставља се да је некропола далеко већа од до сада истраженог простора.
\end{abstract}

Кључне речи: Dacia Mediterranea, Ремезијана, некропола, касна антика, старије гвоздено доба

\section{Увод}

Источна некропола касноантичке Ремезијане налази се на северном обронку брда Велико курило (545 м), које је део Шљивовичког венца (Петровић J. 1998, 23). Некропола је смештена при дну падине која се спушта ка Коритничкој реци (улива се у Нишаву) и Белопаланачкој котлини, пружајући се правцем J-C. Истражени простор је највероватније крајњи северни део некрополе, чија је тачна површина распростирања непозната и наслућује се по остацима гробова и гробница местимично проналажених 


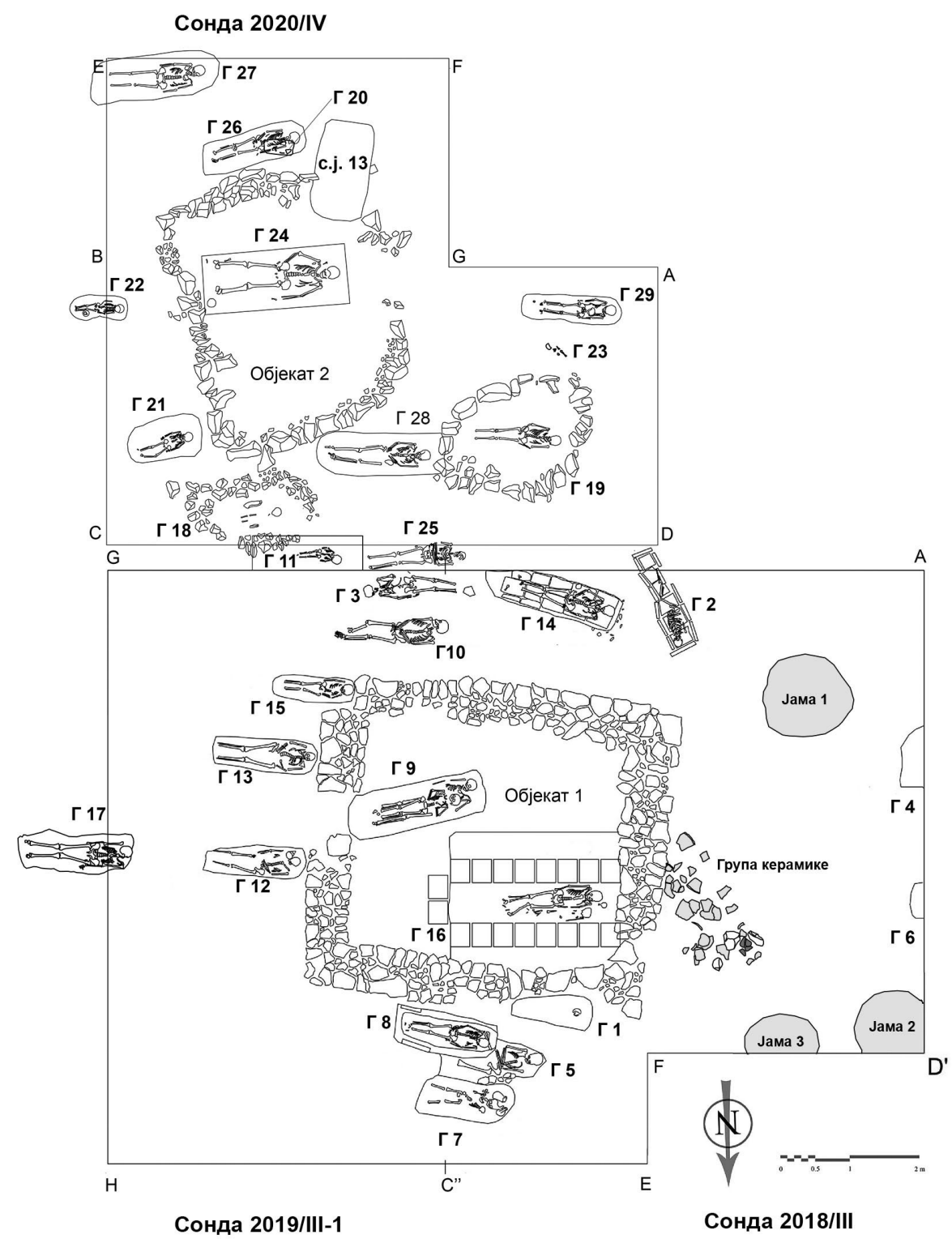

Сл. 1. План истраженог дела некрополе, сонде III/2018, III-1/2019 и IV/2020

Fig. 1. Plan of the excavated part of the necropolis, trenches III/2018, III-1/2019 and IV/2020 
приликом изградње кућа у овом делу Беле Паланке. Изражено савременим топографским одредницама, некропола се налази на простору који уоквиравају улице Николе Деспотовића, Николе Јовановића и Николе Соколовића, а сонде ископане у периоду 2018-2020. позициониране су на око 50 м источно од хотела „Есперанто”, на почетку једног од кракова Ул. Николе Јовановића. Поменути простор био је погодан за формирање некрополе будући да представља релативно заравњену површину на северној падини Великог курила. Ипак, нагиб терена је јасно уочљив и према топографској карти Војногеографског института (Бела Паланка 4-1, 1:25000) налази се на надморској висини између 320 м (на југу) и 300 м (на северу). Крајња јужна површинска тачка на ископаваном простору (у Сонди 2020/IV) налазила се на $\nabla 311,68$ м, док је крајња северна (у Сонди 2018/II) била на $\boldsymbol{\nabla} 307,24$ м. Слично томе, ниво здравице на крајњем југу ископаног простора био је на $\boldsymbol{\nabla} 309,80$ м, док се на северу налазио на $\boldsymbol{\nabla} 305,37$ м. Овај пад терена од око 4,5 м дешава се на растојању од око 50 м, колико ваздушном линијом износи удаљеност између најудаљенијих тачака ископаваних у сондама 2020/IV (на југу) и (на северу) 2018/II (сл. 1).

Судећи по до сада откривеним гробовима, већи део некрополе се налази испод савременог насеља Нова мала, на самој југоисточној периферији модерне Беле Паланке, око 500 м удаљености од остатака утврђења Ремезијане (и савременог центра вароши). Границе некрополе нису до данас јасно дефинисане и о њеном простирању за сада можемо дискутовати искључиво на основу гробова забележених током последњих 130 година. ${ }^{1}$ На основу лоцирања гробова Источне некрополе, за сада можемо говорити о „минималним" границама, док је реална површина коју некропола захвата вероватно већа. Последња истраживања у Белој Паланци, односно прва систематска ископавања Источне некрополе започета су 2018. године у организацији Археолошке збирке Филозофског факултета у Београду. ${ }^{2}$

\footnotetext{
${ }^{1}$ Прве налазе гробова на Источној некрополи, забележили су крајем 19. века Феликс Каниц (Каниц 1985, 201) и Душан Сабовљевић (Сабовљевић 1897, 97-99). Све до 2014. године, на овом простору је откривен већи број појединачних гробова, углавном случајно приликом извођења грађевинских радова (Пејић 2015).

${ }^{2}$ Руководилац истраживања локалитета је др Марко Јанковић. Као чланови екипе, у истраживањима су до сада учествовали др Владимир Михајловић са Одсека за историју Филозофског факултета у Новом Саду, др Александар Бандовић из Народног музеја у Београду, Тамара Павловић са Медицинског факултета у Београду, Димитрије Марковић из Лабораторије за биоархеологију Филозофског факултета у Београду, Петар Голубовић из археолошке збирке Библиотеке Вук Караџић из Беле Паланке, Ана Гавриловић из Београда као и студенти и студенткиње археологије Душка Радосављевић, Ана Остојић, Ненад Андрић, Невена Пантић, Предраг Ђерковић, Немања Павловић и Маша Богојевић. Консултант на пројекту је од почетка колегиница др Гордана Јеремић са Археолошког института у Београду.
} 
Све до 2018. године, на овом простору нису извођена систематска истраживања, већ су подаци о појединачним контекстима углавном резултат извођења и праћења грађевинских радова. На западу, некропола се највероватније завршавала у нивоу данашњег хотела „Есперанто”, односно до Белопаланачког врела у чијој су непосредној близини откривени гробови (Сабовљевић 1887, 98-99). Претпоставља се да је северна граница у висини данашње Улице 11. октобра, односно правца којим је вероватно пролазио пут који је ишао за Турес и даље за Сердику (Пејић 2015), мада истраживања 2018-2020. показују да ову границу вероватно треба делимично ревидирати. ${ }^{3}$ Најисточнија тачка на којој су документовани гробови налази се на простору Улице Николе Јовановића (главни део улице, оријентисан север-југ ${ }^{4}$ ), док бочни део исте улице који је изграђен тако да скреће ка западу, према хотелу „Есперанто”, представља уједно и најјужнију тачку на којој су до сада откривени гробови (сл. 1).

На основу претходних информација, сведочења мештана, али и искуства колега који су се Ремезијаном бавили у претходним деценијама, ${ }^{5}$ одлучено је да се истраживања започну на простору непосредно уз данашњи хотел „Есперанто” (кат. парцеле 2745/2, 2745/3 и 2475/4, К. О. Бела Паланка' ${ }^{6}$ ), односно на јединој већој парцели која још увек није угрожена савременом градњом. Простор је приближно правоугаоне основе, димензија 80 х 50 м и нема савремених грађевина, осим у С3 углу, где се налази савремена трафостаница. Прва истраживања су започета у источном делу парцеле, тачније у његовом североисточном делу, где су отворена два рова димензија 10 х 2 м (2018/I и 2018/II), како би се утврдило простирање некрополе, односно дефинисале њене границе. Сонде 2018/I и 2018/II позициониране су на доњем делу северне падине Великог курила, на катастарским парцелама 2745/3 и 2745/4. Циљ ових сонди била је провера стратиграфије и установљавања да ли се Источна некропола Ремезијане, чије је постојање евидентирано на вишим котама уз Ул. Николе Јовановића, простире и на нижим деловима падине.

\footnotetext{
${ }^{3}$ Наиме, на северном делу парцеле на којој се врше ископавања од 2018. године нису до сада откривени гробови, па у том делу границу треба тражити јужније, у непосредној близини Сонде 2018/III.

${ }^{4}$ Имена улица у насељу Нова мала у Белој Паланци се често понављају, односно постоји више прилаза различито оријентисаних. За потребе сналажења у раду, било је потребно ближе одредити локације. Тамо где је било могуће, наведени су бројеви парцела, док је у осталим случајевима било потребно детаљније описати локацију.

${ }^{5}$ Овде пре свега мислимо на колеге Тонија Чершкова из Завода за заштиту споменика културе Ниш и Зорана Митића из Завичајне збирке у Белој Паланци. Овом приликом им захваљујемо на свим информацијама и помоћи коју су нам до сада пружили.

${ }^{6}$ У време почетка ископавања 2018. године, све парцеле су биле део једне - 2745, која је тек касније подељена на више мањих парцела (2745/1, 2745/2, 2745/3 и 2745/4).
} 
На простору истраженом поменутим двема сондама нису пронађене било какве насеобинске или гробне структуре. Мада је земља садржала покретне археолошке налазе, нарочито уломке касноантичких керамичких посуда, опека, стакла и бронзаног новца, као и керамички материјал из праисторијског периода, њихово присуство се може објаснити процесом спирања тла са виших нивоа падине. Од археолошких ситуација констатована су два укопа, која су, судећи по налазима у њиховим испунама, настала у касноантичком периоду, али чије функције нису јасне (могуће је да се ради о отпадним јамама).

Како у оквиру ровова није било трагова гробних конструкција, отворена је Сонда 2018/III у југоисточном делу парцеле, на приближно 15 м јужно од Сонде 2018/I. Сонда је постављена на заравњеном делу парцеле где је конфигурација терена била видљиво другачија због наводног насипања земље у периоду непосредно пре почетка ископавања, што се на крају испоставило нетачним. На простору обухваћеном Сондом 2018/III откривено је 2018. године укупно 8 гробова и део конструкције од сухозида (Објекат 1) из касноантичког периода. У западном делу сонде, констатован је слој у коме је откривена велика количина покретног археолошког материјала и укопи (Јаме 1-3) из старијег гвозденог доба.

Наредне 2019. године, настављено је истраживање Сонде 2018/III (западни део) а сонда је проширена ка истоку, па је тај простор именован као Сонда 2019/III-1. Димензије ове сонде биле су условљене и просторним ограничењима на терену, односно оградним зидом објекта на парцели бр. 2744 (К. О. Бела Паланка), и износе 8,5 х 4,9 м. Истовремено је настављено са истраживањем гвозденодопског слоја у Сонди 2018/III и са истраживањем конструкције од сухозида (Објекат 1) унутар које су пронађена два гроба. На крају 2019. године укупан број откривених гробних целина из касноантичког периода износио је 16.

Током последње кампање, истраживања су усмерена ка јужном делу парцеле, односно непосредно уз јужне профиле Сонди 2018/III и 2019/III-1, где је отворена сонда 2020/IV. Као и претходних година, почетни план сонде, димензија 8 × 4 м, због открића објекта који је само делимично обухваћен сондом, убрзо је промењен. Сонда је проширена ка југу, а димензије проши-

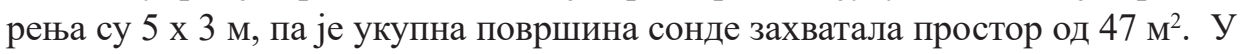
централном делу сонде откривена је фунерарна грађевина (Објекат 2), док је у њеној непосредној близини откривено још 12 гробова, чиме укупан број до сада истражених гробова на локалитету износи 29 (сл. 1). 


\section{Oпште одлике стратиграфије}

Северни обронак брда В. курило на којем је позиционирана Источна некропола Ремезијане условио је површинску конфигурацију терена, односно ерозивно наслојавање тла. (вид. Петровић J. 1998, 50-55). Слојеви тла на северној падини Великог курила налазе на карбонатној/кречњачкој стенској подлози (Петровић J. 1998, 7, 12, 14, 17-18), која представља археолошки стерилан слој (здравицу). Ако се изузму стенска подлога и слој хумуса, наслојавање у сондама постављеним при дну северног обронка В. курила укључује три културно-стратиграфске целине. Најстарија потиче из периода касног гвозденог доба (тј. садржи материјал из ове епохе), налази се на „живој” стени, највеће је релативне дебљине око 1,2 м и може се датовати у 9-7. век пре н. е. Изнад ње се налази слој из касноантичког периода, дебљине до 0,8 м, који се формирао приликом укопавања, употребе и стратиграфског „затварања” некрополе из друге половине 4. века. Последњи културни слој формиран је приликом постепеног наслојавања седимента у последњих 1500 година, али је у њему једино присутан археолошки материјал из последњих стотинак година. Иако су на истраженој површини евидентиране разлике и специфичности на нивоу микропростора и слојеви немају идентичне особине у свим сондама, описана слика може се сматрати општим и основним стратиграфским оквиром за овај део северне падине В. курила.

\section{Касноантичка некропола - преглед гробних целина}

Касноантичка стратиграфска целина садржала је слој земље који је формиран од остатака коришћења Источне некрополе Ремезијане. Поред налаза археолошког материјала у слоју који је „затварао” ниво оригиналне употребе гробља, пронађене су и различите гробне целине, које несумњиво представљају најзначајнију компоненту касноримског слоја на локалитету хотел „Есперанто”. Приликом радова на простору од 143 м² (кат. парцела 2745/2), унутар три сонде (2018/III, 2019/III-1 и 2020/IV), истражено је 29 гробова и у њима су пронађени скелетни остаци 31 индивидуе (два гроба су имала по две сахране). Истражени гробови се грубо могу поделити у две групације концентрисане око два пронађена фунерарна објекта (сл.1): првој припада фунерарни објекат квадратне темељне основе (означен бројем 1) са 14 гробова $(\Gamma 1,2,3,5,7,8,10,11,12,13,14,15,17,25)$ који су се налазили у његовој непосредној близини, док другу групацију чини објекат потковичасте темељне основе (означен бројем 2) са 10 гробова (Г 18, 19, 20, 21, 22, 23, $26,27,28,29)$ који су били распоређени око њега. Унутрашњост пронађених објеката такође је служила за сахрањивање, те су у Објекту 1 пронађена 
два гроба (Г 9 и 16), док је Објекат 2 садржао један гроб (Г 24). Поред ових група сахрана, у западном профилу Сонде 2018/III, само делимично су истражени источни крајеви два гроба (Г 4 и 6) која се простиру ван површине сонде, даље ка западу.

На ископаном простору генерално нису забележена пресецања старијих гробова млађим укопавањима покојника, што сведочи о постојању неке врсте надгробних обележја. Ако се изузму гробне грађевине, које се саме по себи могу узети као монументални фунерарни маркери, остаци гробних белега нису пронађени. Врстом надгробне структуре (ако не обележја у пуном смислу речи) могу се сматрати венци формирани од комада камена средњих и већих димензија који су оивичавали горње површине гробова 18 и 19 (што је забележено и на некрополи у Јагодин мали у Нишу - Јеремић $2014,26)$. Остаје, међутим, нејасно да ли су ови венци учвршћивали мање хумке земље или су једноставно имали улогу граничника гробног места. Изузетак у погледу поремећености приликом каснијег инхумирања показује група гробова са северне стране фунерарног Објекта 1 (квадратне основе), где су евидентирана мања оштећења старијих гробова насталих приликом ископавања млађих гробних рака (гроб 8 је оштетио ЈИ део гроба 5, док су у гробу 7 лобања и керамичке посуде поред ње биле оштећене приликом покушаја укопавања нове гробне јаме). Другачији пример даје гроб 1, чији су покривач и унутрашњост били поремећени, а судећи према укопу који је уочен изнад овог гроба, могуће је да се радило о пљачки.

Скоро сви гробови били су усецани у „живу” стену. Укопавање у кречњачку подлогу било је неједнако и кретало се од „назначавања” простора за полагање тела благим клесањем лежишта, до формирања удубљења и до 0,4 м дубине. Изузеци су једино гробови новорођенчади (Г 20, 23), која је покопавана на мањим дубинама, као и група гробова $\Gamma 3,10,11,25$, чија су се дна налазила на нешто вишим котама од нивоа кречњачке стенске подлоге. Гробне раке препознаване су само у њиховим доњим деловима будући да се испуна у њима јасно уочавала у односу на кречњачку стену у којој су били укопани, док је на вишим нивоима имала исте одлике као тло у које су укопаване раке и од које је и сама била сачињена. Оригинални нивои и горњи обриси ивица гробова препознавани су само у неким случајевима, обично када је испуна садржавала и измрвљени кречњак који је потицао од укопавања дна раке у стенску подлогу (Г 7 и 8), или када је површина гроба обележена венцем од камена (Г 18 и 19). У једном случају (Г 3$)$ горња површина уочена је захваљујући специфичним погребним праксама (видети даље у тексту). Сличан, али мање поуздан случај је и са гробом 22 , изнад којег је пронађена 
концентрација материјала која би могла да означава горњу површину гроба (остаци керамичких посуда, животињских костију и металних предмета).

Ако се изузму ове две сахране, на овој некрополи нису уочени трагови обредне активности у вези са погребним даћама, какви су нпр. забележени на некрополама Виминацијума или Скупа (Зотовић и Јордовић 1990; Јованова 2015). Могуће је да су остаци надгробних гозби и других активности с временом спрани са својих оригиналних места услед нагиба терена и „развлачења” садржаја са површине. С друге стране, једини сигуран изузетак у овом погледу, гроб 3, на својој горњој површини имао је јасне остатке обредних активности, што указује да, када их је било, они јесу могли бити сачувани. У још једном случају (Г 22) посведочена је концентрација животињских костију, комада камена, фрагмената опеке и уломака керамичких посуда, али за ову ситуацију није сигурно да се радило о траговима обредних радњи на површини гроба.

Ни у једном од истражених гробова нису пронађени остаци или трагови дрвених сандука. Налаза клинова, отисака дасака или обриса дрвених носила није било, што упућује на могућност да су тела покојника била обмотана тканином/покровом, или су се приликом полагања налазила у некој врсти вреће. Не може се одбацити ни могућност да су тела директно полагана на дна рака, јер у неким случајевима положаји руку и ногу не указују на умотавање којим су екстремитети били чврсто припијени. Што се тиче оријентације гробова, убедљиво преовлађује полагање тела на леђа, у оси 3-И, са главом на западу, лицем према истоку. Иако се у неким случајевима уочавају блага одступања од поменутог правца полагања тела, само три гроба имају видно другачију оријентацију $(\Gamma 2,9,14)$.

Просторни распоред гробних целина упућује да се на откривеном делу Источне некрополе Ремезијане могло радити о сахранама сродничких група. Постојање гробних објеката у којима се налазе гробови који би се могли окарактерисати као „централни” (због њихове одељености, тј. положаја унутар архитектонске структуре, конструкције гроба и инвентара), којима „гравитирају” појединачне сахране смештене уз њихове зидове и у непосредној близини, упућују на третирање ових грађевина као референтних просторних тачака и на тежњу ка позиционирању осталих гробова што ближе њима. Разумљиво, без ДНК анализа о међусобном сродству сахрањених тешко је било шта рећи са већом поузданошћу, али је пракса груписања гробова око фунерарних објеката различитог типа позната и на другим некрополама из (касно)античког периода (нпр. Симић и др. 2012; Јеремић 2014; Јованова 2015; Стаменковић и др. 2016). 


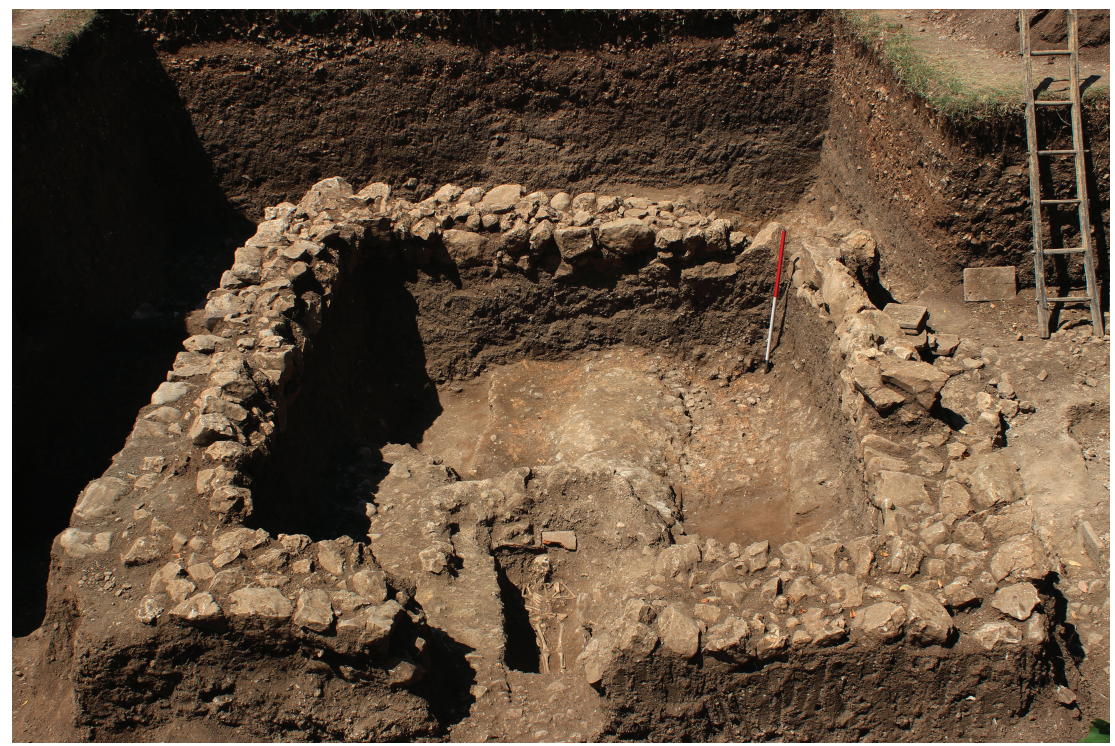

Сл. 2. Меморија од сухозида (Објекат 1) са гробовима 9 и 16

Fig. 2. Drywall memoria (Object 1) with burials no. 9 and 16

Детаљна антрополошка анализа остеолошког материјала са истраженог дела некрополе тек предстоји и стога је немогуће рећи нешто више о полној и старосној структури сахрањене популације. На основу величине скелетних остатака, као и прелиминарног теренског увида антрополошкиње Тамаре Павловић, очит је знатан проценат покојника дечјег узраста: 13 од 31 сахрањене особе. Ова ситуација се уклапа у генералну слику о великој смртности деце у римском периоду и има аналогија у свим боље истраженим некрополама Римског царства.

Врсте пронађених гробова могу се поделити по начину конструкције и у том смислу се разликују гробови у саставу фунерарних објеката, гробови за чије су формирање коришћене опеке и гробови у обичним ракама.

\section{Гробови у саставу фунерарних објеката}

Прва врста гробне структуре представља најсложенији вид конструкције јер подразумева сахрањивање унутар грађевина. На локалитету хотел „Есперанто” приликом досадашњих радова пронађена су две овакве архитектонске целине које се међусобно разликују по типовима којима припадају. Први објекат (у евиденцији означен бројем 1) истражен је у кампањама 2018. и 2019, а од њега су остале сачуване темељне зоне зидова које обухватају правоугаони простор (спољашних) димензија 5,1 х 4,5 м (сл. 2). Ширина зи- 
дова креће се између 0,62 и 0,75 м, а очувана висина од 0,35 до 0,45 м. Њихова очуваност била је неједнака јер су јужни и западни зид најбоље очувани, док је највећу девастацију претрпео северни зид. Техника градње темељних зидова подразумевала је ређање ломљених и притесаних комада камена великих димензија (од 0,25 х 0,1 до 0,6 х 0,3 м), који су остали очувани у висини од два или (местимично) три реда. Везивни материјал није пронађен, али није искључено да је као везиво коришћена земља. Улаз у објекат налазио се на источном зиду и био је ширине 0,95 м. Премда је извесно да је објекат имао и надтемељни део, о којем сведочи пронађени рушевински хоризонт, ништа се не може претпоставити о његовој конструкцији и изгледу јер осим комада камена нису пронађени остаци малтера, кровне опеке и клинови који би могли да потичу од греда. Слично томе, нису уочени ни трагови оригиналне поднице објекта: сасвим је сигурно да она није била поплочана каменом или опекама, а ископавани слојеви нису садржали ни трагове набијене земље, нити трагове који би се могли сматрати остацима дрвеног пода.

Унутар објекта, укопана у здравицу, пронађена су два гроба (Г 9 и 16) са двојним сахранама. Старији, тј. „централни” гроб (Г 16), правца пружања 3-И, налазио се у С3 делу унутрашњег простора и ради се о конструкцији формираној унутар широког укопа у кречњачку стенску подлогу. Најпре је извршено усецање правоугаоног простора димензија 2,4 х 2 м, затим је на јужној и северној страни начињен по један зид од редова хоризонтално положених опека везиваних малтером. Редови зиданих опека су се ка врху постепено сужавали (тј. опеке су биле примицане ка унутра), формирајући „звонасте” профиле на источној и западној страни (оваква профилација зиданих гробова позната је нпр. из Бешке, Сирмијума и Свилоша: Marijanski-Manojlović 1987, 17, 20; Милошевић 2001, 184; Dautova Ruševljan 2003, 75, 77). Северни и јужни зид су били омалтерисани малтерном смесом тамножуте-светлобраон боје, која није била додатно декорисана. За разлику од њих, западна и источна страна коморе нису биле зидане (нити малтерисане), већ су њихова лица била „жива” стена у којој је гроб био усечен. Гробна комора је била затворена низом од седам великих комада камена који су доњим деловима малтером били везани за последњи ред опека. Читава конструкција била је заливена кречном малтерном смесом, чија је горња површина полуобличасто обликована. Унутрашње димензије овако формиране гробне коморе биле су 2,2 х 0,73 м у основи, док је максимална висина (од дна до таванице) износила 1,23 м. У гробној комори пронађени су интактни скелетни остаци одрасле и дечје индивидуе, као и инвентар који је укључивао две стаклене посуде, крстообразну сребрну фибулу, сребрни новчић Констанција II и закивке за обућу. 
Друго гробно место је формирано при самом улазу у објекат, у обичној гробној раци усеченој у стену (правца Ј3-СИ), која је у тренутку откривања само делимично била покривена опекама на источном крају. Овај гроб (Г 9) сигурно је млађи од „централног” и у њему су биле сахрањене две особе: најпре одрасла, а затим, непосредно преко ње, и дете. Судећи по остацима гробног покривача на источној страни где је он остао сачуван, гробно место усечено у стенску подлогу било је покривено хоризонтално положеним опекама које су биле заливене смесом начињеном од земље и кречњака. Овај покривач је расформиран приликом сахране особе дечјег узраста, после чега гроб није затворен на исти начин, већ је гробна рака била испуњена комадима камена већих димензија. За разлику од гроба 16, гроб 9 је од инвентара садржао само новчић кован под Валентинијаном II, који је пронађен у земљи изнад вилице одрасле индивидуе (и стога је вероватно ту доспео приликом инхумације детета).

Описана ситуација са објектом у чијој су унутрашњости извршене четири сахране у два гроба указује на врсту сахрањивања за коју је у домаћој литератури општеприхваћен термин меморија. Ова врста гробне архитектуре заправо означава простор ограђен зидовима чија је унутрашњост намењена за један или више гробова у ужем смислу. Овакав тип градње и организације гробног простора познат је на основу многобројних примера и користио се од раноцарског периода до касноантичког доба у више варијетета (за меморије на подручју Г. Мезије и непосредног суседства видети нпр. Величковић 1964; Цермановић-Кузмановић и др. 1975, 30-34; Milošević 2005; 2014; Јованова 2015, 32-33; Стаменковић и др. 2016; Duplančić 2017; Kurilić and Serventi 2018, 453, 455, 460; Гојгић и Вујадиновић 2019). Објекат 1 се према садржају гробова може датовати у другу половину 4. века, док се његово рушење и престанак употребе може сместити у крај 4. или почетак 5. века (на шта упућује новчић Теодосија I који се налазио у земљи непосредно изнад горње површине сачуваног дела јужног зида грађевине).

Други фунерарни објекат (означен бројем 2) откривен је у кампањи 2020 , око 3 м јужније од Објекта 1. Ради се о темељним зонама зидова који формирају потковичасту основу грађевине: источни зид се пружао праволинијски, док су се, почевши од његових крајева, северни и јужни зид постепено сужавали и својим крајевима на западу образовали апсидални завршетак објекта (сл. 3). Јужни и северни зид се нису додиривали, већ је на простору где би се очекивало њихово спајање констатован прекид ширине 1,1 м, који представља улаз у унутрашњост објекта. Ископани зидови Објекта 2 представљају његову темељну зону која се очувала само у висини око 0,3 м, одно- 


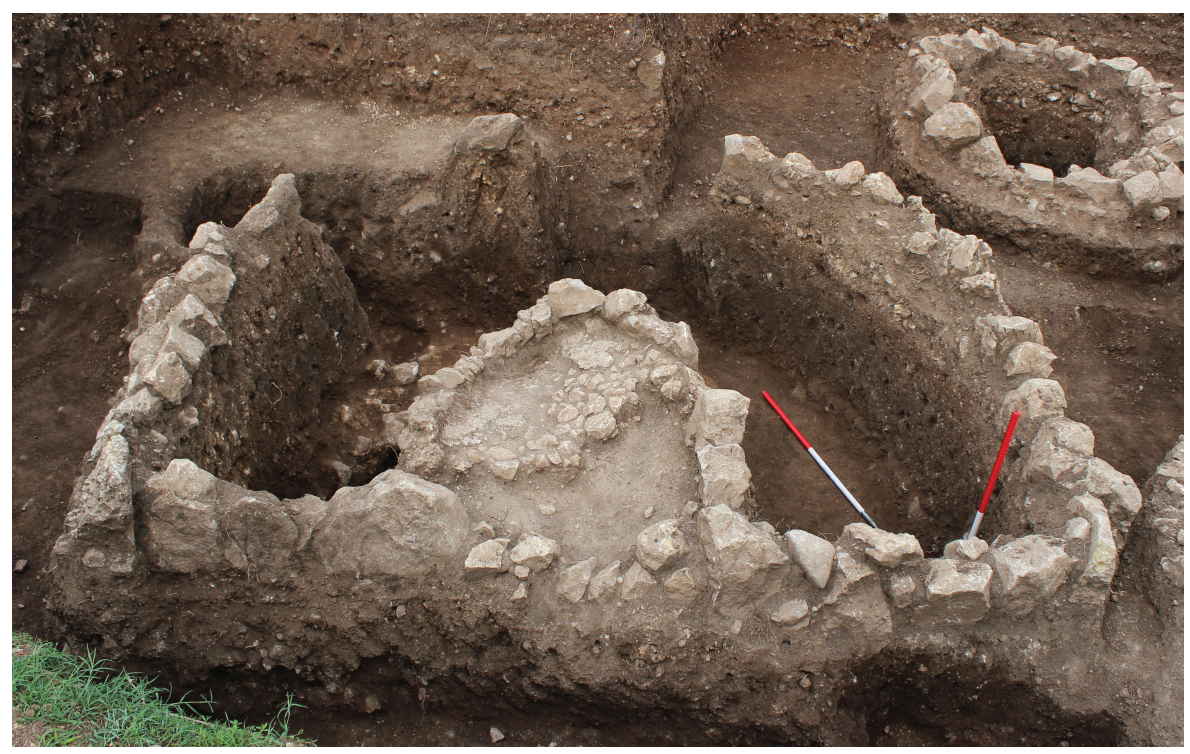

Сл. 3. Конструкција гроба типа менса (Објекат 2)

Fig. 3. The construction of the mensa type tomb (Object 2)

сно у нивоу првог реда камена (већих димензија - од 0,2 х 0,15 до 0,5 х 0,3 м). Максимална дужина објеката (правца 3-И) износи 2,8 м, максимална ширина (правца C-J са одступањем ка западу) - 3,1 м, док је сачувана дебљина зидова 0,3-0,4 м. На очуваном делу зидова који су се састојали од ломљеног и притесаног камена нису пронађени остаци везивног материјала, а трагови малтера in situ констатовани су само на спољашњем лицу северног зида (у дужини од \pm 1 м) и вероватно је да су пре имали декоративну него везивну улогу.

Ни за Објекат 2 нема индиција о надтемељним деловима и кровној конструкцији: иако је врло вероватно да су надтемељни делови развучени после обрушавања, у слоју изнад сачуваних зидова није пронађен рушевински хоризонт, трагови малтера, кровне опеке, нити клинови. Трагови рушења нису констатовани ни на простору између сачуваног нивоа темељних зидова, и отворено је питање какву је врсту надземне конструкције овај објекат уопште могао да има. Нису пронађени ни остаци било какве врсте чврсте поднице, мада јесте уочен ниво који би могао да представља нивелацију унутрашњег простора (изнад које је могла бити формирана ходна површина од земље).

Осим специфичне основе Објекта 2, у његовој унутрашњости пронађена је још једна особена архитектонска структура: на средини источног зида формирана је површина од ређаног камена мањих димензија (у супструктури), оивичена комадима камена средњих величина (око 0,2 х 0,1 м), која је са гор- 
ње стране била омалтерисана. Ова површина је, као и читав објекат, у основи била потковичастог облика (дим. 1,6 х 1,2 м), са полукружним завршетком на западу. Пронађена структура служила је као платформа за постављање менсе (mensa) сигма типа, чији су налази релативно ретки у балканско-панонском делу Римског царства (Gábor 2014, 44; Kurilić and Serventi 2018, 460).

Објекат 2 је претрпео оштећење још у касноантичком периоду будући да је једним укопом био разрушен његов J3 део (у пределу закривљења јужног зида ка северу). Горња површина овог укопа је јасно дефинисана (jер је испуна садржала остатке горења) и на њој су пронађени новчићи, од којих је једини читљив припадао ковању Теодосија I. Намена овог укопа није јасна јер је испуна садржала фрагментоване металне предмете, уломке керамичких посуда, фрагменте животињских костију и опиљке гарежи, али сигурно није била гроб. Пошто је укоп досезао до здравице, могуће је да се радило о (неуспелом) покушају досезања до гроба који се налазио у унутрашњости Објекта 2.

Објекат 2 служио је као ограђени простор за гробно место (гроб 24) у којем је положена једна индивидуа одрасле животне доби. Гроб је формиран унутар правоугаоног усека у кречњачку стенску подлогу (димензија 2,1 x 1,66 м), после чега су све четири његове стране зидане редовима опека везиваних кречним малтером. На овај начин је формирана гробна комора унутрашњих димензија 2,05 х 0,75 х 0,75 м, чија су унутрашња лица зидова била омалтерисана (без фреско-декорације). Комора је била затворена ређаним даскама, преко којих је била наливена смеса од кречњачког малтера: под притиском земље и услед труљења дасака покривач се урушио у унутрашњост гроба, где су пронађени комади малтера са отисцима дасака. У гробу су осим скелетних остатака одрасле особе пронађене и две стаклене посуде (од којих је једна била потпуно смрвљена), бронзана крстообразна фибула и сребрна пређица (вероватно ремена). Специфична архитектура, тип фибуле и хронолошко опредељење укопа који је оштетио архитектонску конструкцију указују да се Објекат 2 и сахрана унутар њега могу сместити у другу половину 4. века.

\section{Гробови са конструкиијом од опека}

Према условној подели којом се овде руководимо, следећа врста фунерарних конструкција укључује употребу опека у формирању гробова у ужем смислу. На локалитету хотел „Есперанто” до сада пронађене фунерарне целине са опеком међусобно се разликују и по обиму употребе ове врсте градивног материјала и по начину конструкције гробова. Од 29 истражених 
гробних целина, не рачунајући гробове у саставу фунерарних објеката, опеке су употребљене у девет случајева (Г 1,2, 8, 11, 14, 17, 20, 21, 28). Само у једном случају (Г 2) радило се о гробу чије су све стране биле формиране од (зидних) опека: дно и покривач од хоризонтално постављених, а четири бочне стране од вертикално постављених опека. У једном случају (Г 14$)$ опеке су употребљене за поплочавање дна гробне раке, простим хоризонталним полагањем у усек формиран у „живој” стени. У једном случају (Г 20) сахрањено новорођенче било је покривено једном опеком. У преосталих шест случајева опеке су употребљене за формирање покривача гроба у ужем смислу, и то у две варијанте. Прва је делимично покривање гроба једноставним хоризонталним ређањем опека, која је пронађена само у једном случају (Г 8): једна већа зидна опека била је у пределу изнад главе сахрањене особе, док је друга била изнад стопала. Друга варијанта је формирање двосливног гробног покривача, било постављањем имбрекса тако да обликују лучни кров (Г 1,11 , $17,28)$, било искошеним постављањем тегула на две воде (Г 21). У четири случаја констатовано је да су доње ивице опека биле уоквириване комадима камена $(Г 2,17,21,28)$, вероватно у својству подупирача (тј. учвршћивања крова пре затрпавања раке). У једном случају (Г 28) врх покривача (тј. спојеви укосо постављених имбрекса) био је покривен редом хоризонтално положених опека, а у једном (Г 11) фрагмент опеке малтером био је везан за врх, вероватно ради учвршћивања покровне конструкције.

Како детаљна антрополошка анализа хуманих остеолошких остатака тек треба да се обави, немогуће је прецизно говорити о полној и узрасној заступљености сахрањених. Ипак, на основу величине скелета, прелиминарно је могуће оценити да правилности у погледу узраста особа сахрањених у гробовима са опекама нису постојале: у четири случаја у њима су пронађени остаци деце (Г 1, 1, 20,21), а у пет су највероватније сахрањени одрасли $(\Gamma 2,8,14,17$, 28). Јаке повезаности између врста и количине гробног инвентара и овог типа гробне конструкције такође нису очите. У три случаја, не рачунајући скелетне остатке, није пронађен други садржај гробова (Г 2, 20, 21). У једном гробу (Г 11) пронађен је само бронзани новчић (Константин II), а у једном, додуше девастираном (Г 1), фрагменти стаклених перли, који су вероватно потицали са ниске огрлице или наруквице. У једном гробу (Г 17) пронађена је бронзана копча у појасном пределу скелета, као и тракасти фрагменти гвозденог предмета који би могао бити део фибуле или наруквице. Три преостала гроба имала су бројнији инвентар, у којем су преовладавали функционални делови одеће и накит. Тако је у гробу 14 пронађена група предмета коју су чиниле перле за ниску огрлице, златне наушнице, наруквица од гвожђа, две стаклене посуде и 
бронзани новчић. Гроб 8 садржао је бронзану и коштану наруквицу, сребрни прстен и перле за огрлицу, док су у гробу 28 пронађене четири наруквице од бронзе и перле са огрлице.

Ни у једном од гробова са опекама нису пронађени клинови који би могли да потичу од сандука, те је највероватније да су покојници били умотавани у тканину, односно да су полагани заједно са покровом чији се остаци нису очували. Хронолошки, гробни инвентари и општа стратиграфска слика упућују да су сахране у овом типу гробне конструкције обављене у другој половини 4. века. Све карактеристике ове врсте фунерарне конструкције имају паралеле у готово свим другим касноантичким некрополама на подручју балканско-панонских провинција (и шире) те се слободно могу означити као уобичајени начин формирања гроба (видети нпр. Göricke-Lukić 2000, 18; Petković et al. 2005, 129-131; Јеремић 2014, 27; Kurilić and Serventi 2018, 455).

\section{Гробови у обичним ракама}

Иако су сви гробови пронађени ван фунерарних објеката имали обичне јаме на чијем дну су полагани покојници, овај термин се односи на случајеве у којима нису забележени конструктивни елементи пода или покривача гробног места у ужем смислу. На истраженом простору локалитета хотел „Есперанто” таквој врсти покопавања умрлих припада 15 гробова (Г $3,5,7,10,12,13,15,18,19,22,23,25,26,27,29) .{ }^{7}$ Као што је већ поменуто, готово сви гробови на истраженом делу Источне некрополе Ремезијане смештани су на дну рака које је било образовано усецањем у кречњачку стенску подлогу (дубина од 0,1 до 0,4 м). Изузетке од ове праксе представљају гробови новорођенчади $(\Gamma 20,23)$ укопаних на приметно вишим котама од свих осталих гробове, као и гробови 3,10, и 25 , чија су дна била за 0,1-0,2 м изнад „живе” стене. Горње површине гробова и ивице укопа веома ретко су могле бити дефинисане јер се испуне гробних рака нису разликовале од околног слоја (од којег су и настале). У два случаја је откривен венац од камена који је у неправилном овалном (Г 19) и правоугаоном (Г 18) облику уоквиривао горњу површину гроба. У четири случаја $(\Gamma 3,7,8,22)$ специфични је садржај испуне раке омогућио установљавање њене горње површине, односно оригиналног нивоа са којег је извршено покопавање. Подваријантом гробова у обичним ракама могу се сматрати случајеви где је простор на дну, предвиђен за полагање тела, био оивичен комадима камена средњих и већих димензија, што показује пет примера $(\Gamma 5,18,19,22,23)$.

\footnotetext{
${ }^{7}$ Типу сахране у обичној гробној јами припадају и гробови 4 и 6 , али пошто они нису истражени у целости, овде их и не узимамо у разматрање.
} 
Ни у гробовима унутар обичних рака нису забележени остаци који би могли да индицирају употребу дрвених сандука. Вероватно су тела била умотана у тканину или неку врсту платнене вреће, за шта назнаке пружа сахрана новорођенчета (Г 23) чији су остаци били у положају који се може објаснити спуштањем вреће са телом у претходно ископану гробну јаму (лобања је била на вишој коти него стопала).

Када је реч о узрасту сахрањених унутар простих гробних јама, судећи по величини скелета, у осам случајева радило се о сахранама деце и у осам о одраслим особама. Иако је на основу малог броја гробова тешко говорити о неким правилностима, гробови деце су генерално сиромашнијег гробног инвентара. У три случаја $(Г$ 18, 20, 23), од која два припадају сахранама новорођенчади, није пронађено ништа осим остеолошких остатака. У једном гробу детета (Г 26) пронађен је само бронзани новчић (Константин ІІ), у једном (Г 29) гвоздена карика у пределу стопала, и у једном (Г 15) перле од ниске огрлице. У гробу 22 пронађена је керамичка посуда (и испод ње два млечна зуба), а у гробу 7 две керамичке посуде, бронзана наруквица, бронзана карика, бронзано дугме и перле за огрлицу. Осим што поменута два гроба представљају једине случајеве прилагања керамичких посуда на до сада истраженом делу некрополе, гроб 7 је и сахрана особе дечјег узраста са најразноврснијим садржајем.

Од сахрана одраслих особа у једном није пронађено ништа од инвентара (Г 10); један (Г 25) је садржао само гвоздене закивке за обућу; један (Г 5) фрагмент бронзане игле; један (Г 3) наушнице од јако лоше сребрне легуре са висуљкама од калцита; један (Г 13) бронзану наруквицу и фрагмент друге наруквице (код ногу); један (Г 27) перле од огрлице и бронзани прстен код ногу; један (Г 12) стаклену посуду и три новчића (од која је једини читљив кован у време Констанција II); и један (Г 19) бронзану луковичасту фибулу, гвоздени стилус и бронзану пређицу. Као што се може видети, број и врсте гробног инвентара у појединачним гробовима се крећу у ограниченом распону једног или неколико комада личног накита и функционалних делова одеће, и само су у ретким случајевима били укључени предмети попут стаклене посуде или стилуса. Уопштено узевши, истражени гробови у простим јамама не показују одступања од особина ове врсте сахрана које су познате са других касноантичких некропола диљем Римског царства.

Два гроба из ове групе могу се издвојити као изузетни, и то Г 3 , који представља особену појаву у пуном смислу речи, и Г 22, који донекле одступа од уобичајених образаца касноантичке фунерарне праксе. Гроб 3 припада врсти тзв. девијантних сахрана јер је индивидуа на дну раке пронађена у положају потрбушке, са лицем према земљи. Другим речима, тело је или 
бачено у претходно припремљену јаму, или је намерно постављено у овакав положај. Осим тога, испуна овог гроба садржала је земљу која је у себи имала и пепељасту материју (можда се радило о пепелу умешаном са земљом) и била измешана са великим бројем уломака горелих керамичких посуда. Горња површина овог гроба је препозната управо захваљујући специфичности испуне, али и концентрацији животињских костију, фрагмената керамике и фрагментованих металних предмета. Пошто је реч о особеном археолошком контексту, ова гробна целина биће предмет посебне анализе.

Гроб 22, у којем је сахрањено дете, такође је на горњој површини имао концентрацију од камена, фрагмената опеке и фрагментованих животињских костију, за коју постоји могућност да представља остатак неких обредних активности. Ово је мање поуздано него у случају гроба 3 будући да се, осим ове површине, остатак испуне гробне раке није разликовао од слоја у којем је био укопан, односно у њему нису пронађени уломци горелих посуда, нити друге врсте артефаката. С друге стране, налаз два млечна зуба испод нагореле керамичке посуде која се налазила поред левог колена покојника у гробу 22, отвара могућност обављања специфичних погребних радњи које су можда укључивале и „даћу”. Што се осталих гробова тиче, нису уочене било какве индиције погребних обреда, мада је у 3 случаја пронађен један или неколико комада камена преко скелетних остатака (изнад предела груди - Г 27, 29, изнад предела карлице - Г 10). Ипак, ни за један од ових примера није сигурно да ли се радило о намерном полагању камења, или је оно у раку убачено приликом затрпавања и на те положаје доспело приликом даљих тафономско-стратиграфских процеса.

\section{Покретни археолошки налази из гробова}

Од укупног броја гробова (29), у 21 гробу су откривени предмети који се могу тумачити као део гробног инвентара, док је у 8 гробова садржај чинио само хумани остеолошки материјал. ${ }^{8}$ Предмети откривени у гробовима могу се посматрати кроз неколико већих група - новац, накит (ниске, прстење, наруквице, игла), делови и украси за одећу и обућу (фибуле, копче, игле и шунегле), керамичко и стаклено посуђе. У посебну групу предмета треба издвојити налаз гвозденог стилуса из гроба 19, који је откривен у фрагментима и лошем стању (сличан је пронађен у купатилу на локалитету Mansio Idimum - Vasić i Milošević 2000, 205, kat. br. 33).

\footnotetext{
${ }^{8}$ У овај број спадају два гроба која су само делимично истражена $(\Gamma 4,6)$, два која припадају новоређанчади $(\Gamma 20,23)$, два у којима су сахрањена деца $(\Gamma 18,21)$ и два у којима су почивали одрасли $(\Gamma 2,10)$.
} 


\section{Новац}

На локалитету је до сада откривено укупно 40 примерака, већином бронзаног новца, од чега је мањи део (8 комада) пронађен у оквиру затворених гробних целина (Г 9, 11, 12, 14, 16 и 26). Док су два новчића нечитљива (Г 12), остали су идентификовани као ковања Константина II (Г 11 и 26), Констанција II (Г 12, 14 и 16) и Валентинијана II (Г 9). Седам новчића је израђено од бронзе, док је један са ликом Констанција II, откривен у оквиру гроба 16, израђен од сребра. Оба новчића Константина II искована су у време док је носио титулу цезара (301-337), један у ковници у Сисцији (Г11) а други у Антиохији (Г26). Оба новчића су такође на реверсу имала исту легенду - GLORIA EXERCITVS. Новац кован у време Констанција II најбројнији је, како на читавом локалитету, тако и на примерцима откривеним у гробовима. На новчићу кованом у Солуну (Г12) реверсна представа је читљива само делимично и вероватно се ради о обореном коњанику. На примерку из гроба 14 не види се податак о ковници, али је текст на реверсној страни читљив FEL TEMP PREPARATIO. Новчић из гроба 16 представља врло редак сребрни милиаренсис, који је до сада познат у свега неколико примерака у свету (RIC VIII, 48, варијанта B). На аверсу је представа Констанција II са текстом CONSTANTIVS PF AVG, док је реверс украшен вотом у венцу са натписом SIC X/ SIC XX и текстом GAVDIVM POPULI ROMANI. И овај примерак је кован у Сисцији, највероватније у периоду 337-340. године (Kent 1981, 353). Најмлађи примерак новца из гробова, кован у време Валентинијана II (375-392), откривен је у гробу 9. Иако је у доста лошем стању, делимично су видљиви представа и име цара, као и вота на реверсу VOT X/MULT.

\section{Накит}

Свакако најбројнију врсту накита откривену до сада на Источној некрополи Ремезијане представљају перле, односно ниске од перли. У највећем броју случајева ради се о стакленим перлама црне, индиго, тиркизне и зелене боје $(\Gamma 1,7,8,14,15,27$ и 28), док су у једном случају детектоване и перле од ћилибара (Г 7). У случају гроба 28 , поред стаклених перли, откривени су и завршеци ниски у виду танких бронзаних омчи. Само у једном гробу (Г 1) откривене перле су истог типа и боје, док се у осталим случајевима ради о комбинацијама облика (цилиндричне, биконичне и коничне перле, перле полигоналног пресека или лоптасте перле), боје (бела, различите нијансе плаве и зелене, црна) или материјала (стакло и ћилибар). Стаклене перле су уобичајен налаз на касноримским некрополама и до сада су откривене у великом броју гробова на некрополама у Гладном пољу код Беле Паланке (Ружић 
2017, 220), Јагодин мали (Јеремић 2014, 88-92), Слогу код Равне (Petković et. al. 2005, 347-348), Бешки (Marijanski-Manojlović 1987, 63). Перле од ћилибара су нешто ређе од оних стаклених, али су такође детектоване на више локалитета - Јагодин мали (Јеремић 2014, 91), Пећинама код Виминацијума (Крунић 2006, 373), Слогу код Равне (Petković et. al. 2005, 65).

Прстење је на Источној некрополи до сада откривено свега у два случаја - један сребрни примерак је откривен у гробу 8 , док је други, бронзани, откривен са покојником у гробу 27. Прстен из гроба 8 израђен је од лошег сребра у виду алке кружног пресека, док је бронзани примерак из гроба 27 сачуван у бољем стању. Бронзани прстен има профилисану главу са нејасном представом на горњој страни (храстов лист?). По форми сличан прстен, откривен је на некрополи у Јагодин мали (Jovanović 1978, 19-20).

Наушнице су откривене у две гробне целине. Први пар наушница је откривен у гробу 3 , као једини предмет откривен уз тело покојнице. Ради се о наушницама израђеним од сребра веома лошег квалитета, што је резултирало и лошим стањем у којем су откривене. Код једне од наушница је делимично сачувана алка на коју је окачен привезак у виду намотаја жице који се завршава белим каменом (калцитом) лоптастог облика. Сличне наушнице се чувају у колекцији Дуњић, у Народном музеју у Београду (Ratković 2013, 130-131). Други пар наушница је откривен у гробу 14: ради се о примерцима израђеним од злата и црног камена, вероватно граната (сл. 4). За разлику од претходних, овај пар је сачуван у изузетно добром стању. Наушнице су израђене у виду алки са копчом, на којима висе полигонални звонолики привесци. Кроз унутрашњост привезака уметнута је жица на чијим крајевима је привезан камен. Најближа аналогија овим наушницама потиче са непознатог локалитета у Белој Паланци (Jovanović 1978, 135), а слични примерци су откривени на некрополи Слог код Равне (Petković et al. 2005), у Нишкој Бањи (Дрча 2004, 192), док се један чува у колекцији Народног музеја у Београду, а потиче са непознатог налазишта (Поповић 2001, 128, кат. бр. 44). Сви примерци се датују у 4. век, што одговара и условима налаза са Источне некрополе.

Наруквице су откривене у већем броју гробова $(\Gamma 7,8,13,28)$, а израђиване су од бронзе $(\Gamma 7,8,13$ и 28) и кости (Г 8). У гробовима 7, 8 и 13 су нађене по две, а у гробу 28 четири наруквице. О коштаном примерку се упркос фрагментацији може рећи да је вероватно имао преклопљене крајеве спојене бронзаном нитном а био је украшен урезивањем тзв. окаца и концентричних кругова са спољашње стране. Такве наруквице на простору Србије нису честе и једини примерци (фрагментовани) потичу са локалитета Дијана (Petković 1995, 88, kat. br. 429) и Гамзиград (Живић 2003, 124. кат. бр. 


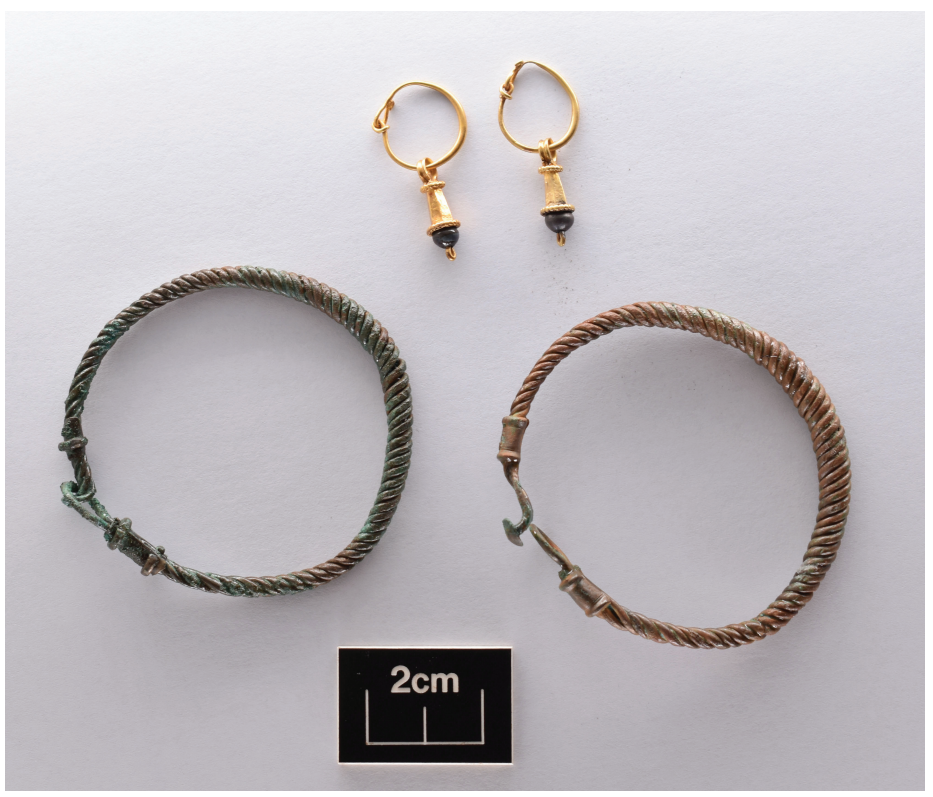

Сл. 4. Избор накита из гробова - наушнице (гроб 14) и наруквице (гроб 28)

Fig. 4. The selection of jewellery - earrings (burial no. 14) and bracelets (burial no. 28)

195-197). У гробу 7, у којем је сахрањено дете, откривен је пар наруквица малих димензија од танке бронзане жице са крајевима спојеним једноставном петљом. Код гроба 8 је нешто другачија ситуација јер су две откривене наруквице израђене од различитих материјала - једна, већ поменута, од кости и друга од бронзе. Бронзана наруквица је израђена од жице са отвореним и проширеним крајевима, могуће у виду јако стилизованих змијских глава, слична наруквицама откривеним на локалитетима Јагодин мала (Јеремић 2014, 71) и Слог код Равне (Petković et. al. 2005, 72). Једна фрагментована и једна цела бронзана наруквица откривене су у гробу 13. На фрагменту се види орнамент сличан оном на коштаној наруквици, односно урезане линије и окца. Ипак, питање је да ли је овај фрагмент наруквице део гробног инвентара јер је откривен у испуни гроба. Друга наруквица је другачија и има крајеве изведене тако да се један, тањи увлачи у цилиндрично проширење на другом крају. Сличан примерак је откривен током истраживања некрополе у Јагодин мали (Јеремић 2014, 72), али и на локалитетима Бешка (MarijanskiManojlović 1987, 150) и Земун Поље (Петровић 1997, 127, кат. бр. 138). У гробу 28 откривене су четири наруквице, две у виду тордиране жице са куком и алком на крајевима (сл. 4), једна од танке жице са преклопљеним крајевима и навојима жице и једна масивна наруквица са задебљаним крајевима. 


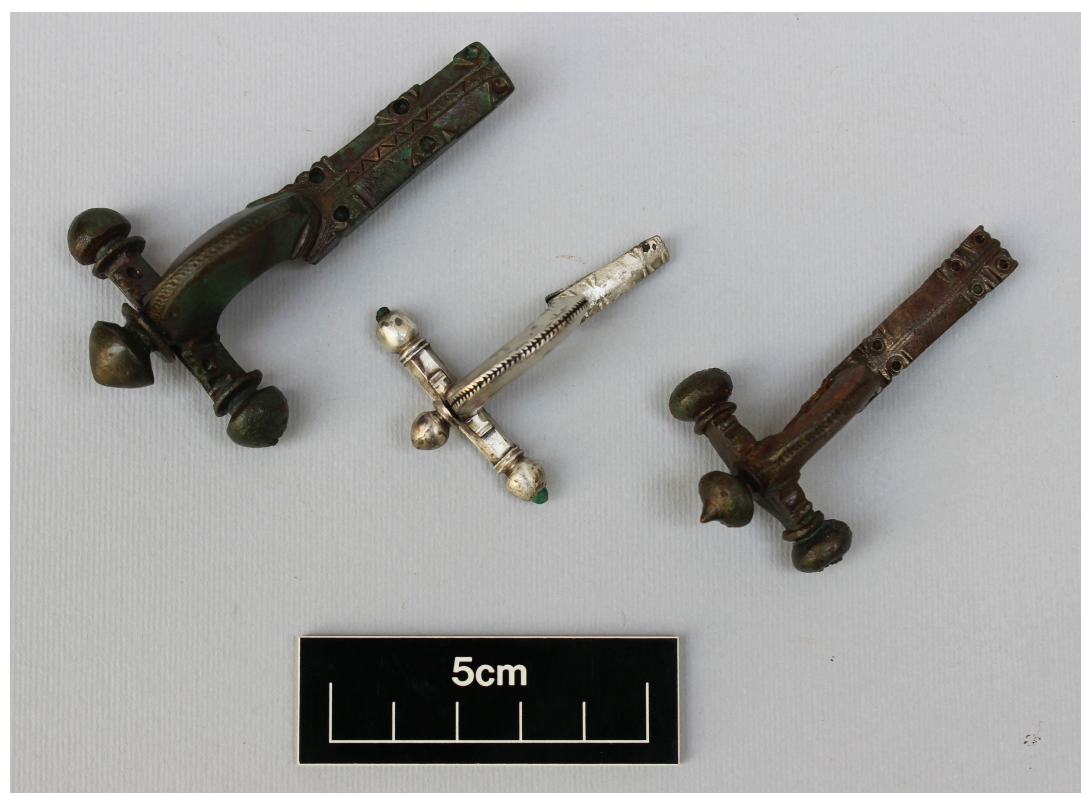

Сл. 5. Фибуле из гробних целина - (гробови 24, 16 и 19, здесна налево)

Fig. 5. Fibulae from the burials - (burials no. 24, 16 and 19, right to left)

Наруквице од тордиране жице откривене су већ на некрополама Гладно поље код Беле Паланке (Ружић 2017, 219, сл. 5/18a; 221, сл. 6/47в), Слог (Petković et. al. 2005, 72-73), Пиривој (Milovanović 2018, 129) и Бешка (MarijanskiManojlović 1987, 113; 122; 129). Наруквице са преклопљеним крајевима откривене су у непосредној околини, односно на некрополи Гладно поље код Беле Паланке (Ружић 2017, 221), док су наруквице са задебљаним крајевима налажене у оквиру гробних целина на локалитетима Јагодин мала (Јеремић 2014, 77) и Слог код Равне (Petković et. al. 2005, 72).

\section{Функиионални делови одеће и обуће}

У ову групу предмета спадају они који поред некад декоративне имају и јасну функционалну улогу, односно представљају делове одеће и обуће са којима је покојник сахрањен. Овакви предмети се не тумаче као гробни прилози, већ се посматрају као део личне опреме покојника.

Фибуле

У гробовима Источне некрополе Ремезијане откривене су укупно три фибуле - једна сребрна откривена у гробу 16 и две бронзане из гробова 19 и 24 (сл. 5). Сребрна припада типу крстообразне фибуле са кратком сто- 
пом и луком трапезоидног пресека. На крајевима се налазе полигоналне луковице, док је попречна греда ојачана на месту где се спаја са луком. Лук је са горње стране фасетиран у виду непрекидних троуглова попуњених нијело пастом. Стопа је украшена урезима и благо се сужава ка крају. Игла фибуле је очувана у целости и израђена је од бронзе. По типологији С. Петковић ова фибула припадала би типу 34 , и то вероватно варијанти А, која се најчешће датира у период 284-324. г. н. е. (Petković 2010, 259). Примерци слични овом из гроба 16 откривени су на неколико места на територији данашње Србије - Заскок код Урошевца (Поповић 1994, 308; Фидановски 1998, 294), Брестовик (Поповић 1994, 336). Овом типу припада и фибула са непознатог локалитета која се чува у Народном музеју у Београду (Petković 2010, 259).

Други примерак потиче из гроба 19 и ради се о бронзаној фибули типа 34D, који се датује у време између владавине Валентинијана I и Валенса до доласка Теодосија I на власт - 364-380. г. (Petković 2010, 266). Овај тип фибула је уједно и најзаступљенији тип међу крстообразним фибулама и чини готово четвртину свих налаза са територије Србије. Фибула има масивни лук трапезоидног пресека, украшен урезивањем непрекидног низа троуглова. Полигонална, профилисана греда завршава се изразитим луковицама, а стопа је украшена утиснутим „окцима” (два код споја са луком и четири на супротном крају). Игла фибуле је израђена од гвожђа. Сличне фибуле су откривене на некрополама Гладно поље код Беле Паланке (Ружић 2017, 225, Г40), у Бешки, Свилошу, Виминацијуму (Petković 2010, 265), Гамзиграду (Petković 2011a, 129) и некрополи Слог код Равне (Petković et. al. 2005, 351, P1. 5/3).

Фибула из гроба 24 припада истом типу као и претходна, док се основна разлика види у начину украшавања стопе - окца су распоређена равномерно, односно по два окца на крајевима и два у средини, док је средишњи простор стопе украшен непрекидном цикцак линијом. Попречна греда је профилисана и има две перфорације, по једну са сваке стране лука. Последња разлика се односи на чињеницу да је игла, као и остатак фибуле, израђена од бронзе.

\section{Украсни делови одеће и обуће}

На некрополи су у два гроба откривене и две копче - једна бронзана у гробу 17 и једна сребрна у гробу 24. Бронзана копча је правоугаоног облика и правоуглог пресека, са трном изведеним савијањем око окова. Према димензијама и месту налаза, ради се о појасној копчи. Сличан примерак је откривен на локалитету Пећине (Виминацијум) и датује се у последњу тре- 
ћину 4. века (Реџић 2013, 170). Новчић откривен у испуни раке, над гробом 17 , у коме је откривена ова копча, кован је у време Валентинијана II, што се слаже са предложеним датовањем. Као аналогни могу да се наведу примерак откривен на Салдуму (Jeremić 2009, 199, Cat. no. 647), и још два са Гамзиграда - (Petković 2011b, 186, Fig. 159; 195, Fig. 168).

Код другог примерка, израђеног од сребра, сачувани су алка са трном и оков са три нитне којим је копча била припојена за кожни каиш. И у овом случају се радило о појасној копчи будући да је пронађена у карличном пределу скелета. Сребрне копче овог типа нису уобичајене, и једини сличан примерак откривен је на локалитету Пећине (Реџић 2013, 130).

У једном од гробова (Г 19) откривена је бронзана копча/пређица мањих димензија која је могла да служи за неки бочни ремен, ако се има у виду да је пронађена у раменом пределу покојника. Сачувана је алка са трном као и део окова са једном нитном којим је пређица спајана са кожним ременом. Најближу аналогију овом примерку чини пар копчи сличних димензија откривен као део гробног налаза на некрополи Слог код Равне (Петровић и Јовановић 1997, 115).

Кад говоримо о овој групи налаза, треба свакако споменути и бронзано дугме/нитну и бронзану карику откривену у гробу 7 , као и гвоздену алку из гроба 29. Нитна је откривена у пределу карлице па се претпоставља да се ради о нитни за појас или одећу. Кружног је облика и на њој се са унутрашње стране види део осовине који недостаје. Због фрагментованости, није било могуће утврдити тип, нити дати ближе аналогије. Слично је и са гвозденом алком из гроба 29 , чију је намену у овом тренутку немогуће утврдити. Нешто је другачија ситуација са бронзаном кариком чији се један крај сужава а други је изведен у облику стилизоване змијске главе. Сличан примерак је откривен на локалитету Врањ код Хртковаца (Dautova-Ruševljan 2016, 71; T. 29).

До сада је на некрополи откривена само једна, и то фрагментована бронзана игла (Г 5), о којој се нажалост не може много рећи с обзиром на степен очуваности.

У гробу 25, откривено је укупно 138 гвоздених закивака за ђон обуће малих димензија - шунегли. Нажалост, ови налази су мањим делом документовани in situ. Они говоре о томе да је покојник био сахрањен са сандалама или неким сличним типом обуће. Трагови шунегли откривени су и у оквиру гроба 16, али су предмети били у веома лошем стању, те не можемо говорити ни о броју нити евентуалном распореду. Такви случајеви су докуметовани на Малој Копашници (Стаменковић и др. 2016, 30) и на локалитету Пиривој (Raičković i Milovanović 2009, 24). 


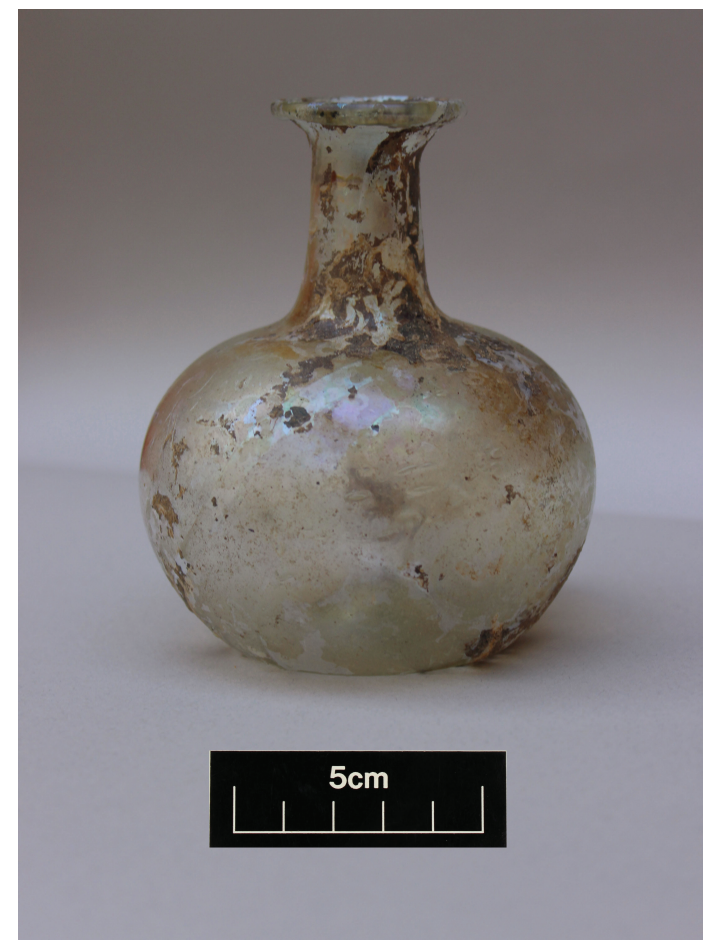

Сл. 6. Стаклена боца из гроба број 16 (Објекат 1)

Fig. 6. Glass bottle from burial no. 16 (Object 1)

\section{Стаклено посуће}

На Источној некрополи је до сада откривен велики број појединачних фрагмената стаклених посуда у слоју. Због степена фрагментације најчешће се не може дискутовати о формама и облицима, као ни о броју посуда на основу појединачних фрагмената. Ипак, у неким гробовима откривене су посуде у добром стању, или је in situ документована њихова форма. Стаклено посуђе је пронађено у гробовима $\Gamma 13,14,16$ и 24 , док су у испунама гробова Г $8,9,17$ и 25 откривени појединачни фрагменти, па није искључено да су ту доспели током затрпавања. У сваком случају, овде ћемо се посветити оним предметима чији се форма и облик могу препознати.

У гробу 13 откривен је фрагментован конични пехар од безбојног стакла украшен у горњој половини плавим окцима у облику грозда. Са спољашње стране левкастог обода, налазе се две паралелне канелуре, док се још две канелуре виде непосредно изнад и испод дела украшеног окцима. Конични пехари мањих и већих димензија познати су са некропола у Пољаницама (Фидановски 1998, 280, кат. бр. 280-281), Јагодин мали (Јеремић 2014, 119) и 
Слогу (Petković et. al. 2005, 350, Pl. 4/1 и 3), док је украшавање плавим окцима широко распрострањено како на оваквим пехарима, тако и на стакленом посуђу других форми (нпр. Ružić 1994, T. XXXIII, XXXIV, XXXV, XXXVII; Дрча 2000, 218; Jeremić 2009, 146-147). Овакве пехаре М. Ружић у својој типологији стакла смешта у тип пехара VII/12c (Ružić 1994, 93).

У гробу 14 откривене су две стаклене посуде, код којих се, иако су фрагментоване, може препознати тип посуде. Прва посуда, откривена код ногу припада типу тоалетних бочица - балсамаријума прстенастог обода, дугог цилиндричног врата и реципијента са четири удубљења. По типологији Мире Ружић могла би се сместити у неку од варијанти типа III/10 (Ružić 1994, 88). Друга посуда припада типу боца са разгрнутим прстенастим ободом и цилиндричним вратом који се шири у лоптасти трбух са конкавним дном. Овај тип боце је прилично уобичајен и налажен је на локалитетима у Сремској Митровици, Костолу, Равни, Свилошу и др., а М. Ружић овакве боце смешта у тип I/7 (Ružić 1994, 84). Истом типу посуде припада и стаклена боца из гроба 16 , откривена изнад главе покојника (сл. 6). Обе боце су израђене од безбојног стакла. Последња стаклена посуда чији се облик може препознати откривена је код ногу покојника у гробу 24. Иако фрагментована, у току истраживања је документована па се може дискутовати о њеној форми. Највероватније се ради о благо коничној стакленој здели браон боје са плитким жлебом испод равног обода и прстенастим дном, какве су по типологији М. Ружић смештене у тип IV/6b (Ružić 1994, 90). Сличне зделе су откривене на локалитетима Београдска тврђава, Чезава, Брза Паланка и Улпијана (Ružić 1994, 38).

\section{Керамичке посуде}

Поред извесне количине фрагмената керамике, на некрополи су откривене и три целе керамичке посуде - две у гробу 7 и једна у гробу 22 (сл. 7). Обе посуде из $Г 7$ делимично су оштећеног обода, услед оштећења гроба 7. Први примерак представља крчаг са једном дршком која полази од обода. Израђен је од добро пречишћене глине а на спољашњости се виде трагови горења. Крчаг има широки тролисни обод, цилиндрични врат и ниски трбух који се завршава равним дном. Слични примерци откривени су на некрополама у Гладном пољу код Беле Паланке (Ружић 2017, 233, сл. 9/24-25), Јагодин мали (Јеремић 2014, 142) и Слогу код Равне (Petković et. al. 2005, 355, Pl. 9/6), а по типологији Т. Цвјетићанин припадају типу К28 (Цвјетићанин 2016, 60-61). Друга посуда је такође крчаг са прстенастим ободом, цилиндричним вратом и лоптастим трбухом. При равном дну је благо изражена стопа а тракаста дршка полази нешто испод ивице обода. На посуди је у већој мери сачувана 


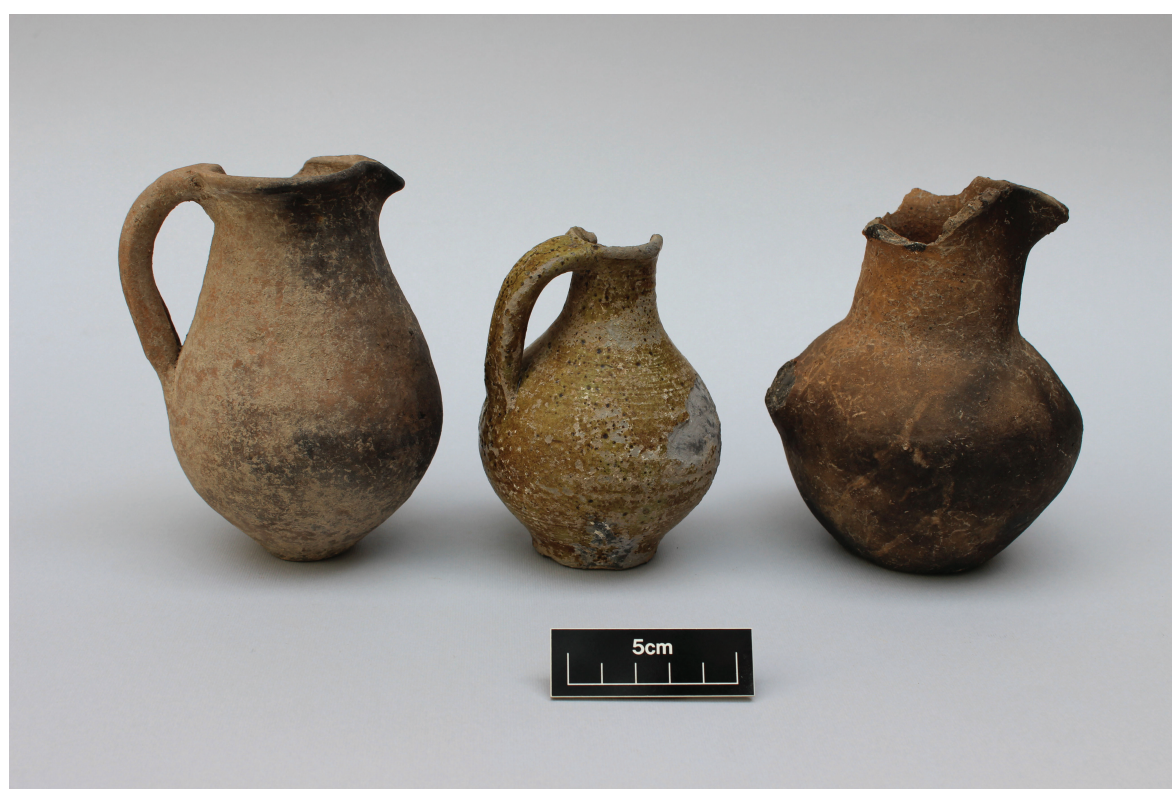

Сл. 7. Керамичке посуде из гробова 7 и 22 (здесна на лево)

Fig. 7. Ceramic vessels from burials no. 7 and 22 (right to left)

маслинасто-браон глеђ, а видљиве су и паралелне плитке канелуре на трбуху и ободу. Овакви крчази су такође откривени на некрополи у Јагодин мали (Јеремић 2014, 147), а припадају типу КАГ87 (Цвјетићанин 2006, 63). Последњи крчаг, из гроба 22, већ је делимично био оштећен приликом полагања у гроб. Наиме, део обода и цела дршка недостају, а на читавој површини се виде трагови горења. Крчаг има широки тролисни обод, цилиндрични врат и биконични трбух са равним дном. Рађен је од добро пречишћене глине, а на спољашњости нема трагова декорације. Овакав крчаг припада истом типу (К28) као и крчаг из гроба 7. Сви крчази се на основу типолошких одлика и аналогија са других локалитета датују у 4. век.

\section{Културни слој гвозденог доба}

Током три кампање 2018-2020. године у свим сондама проналажени су уломци керамике из старијег гвозденог доба. У сондама 2018/I и 2018/II, које су истраживане 2018. године, највећи број керамичких фрагмената као и спорадични остаци кућног лепа, доспели су у слој приликом спирања са виших тачака брда. Нешто је другачија ситуација затечена у сонди 2018/III, у којој су током кампање 2019. године пронађени већ описани остаци касноантичке меморије и гробови. Активности везане за настанак некрополе про- 
узроковали су очигледно поремећај праисторијског културног слоја, што се јасно може сагледати према присуству фрагмената праисторијске грнчарије у испунама рака неколико касноантичких гробова. Ово је, без сумње, последица укопавања касноантичких гробних јама кроз праисторијски слој, који је затим враћан у ископ као испуна гробних рака. Такође, археолошки материјал из гвозденог доба јављао се површином читаве Сонде 2018/III, заједно са касноантичким и рецентнијим материјалом, што је највероватније последица ерозије са виших кота, или преоравања падине у другој половини 20. века.

На просторима који нису били обухваћени формирањем касноримских укопа, праисторијски слој је остао интактан и састојао се од земље помешане са уломцима керамичких посуда и фрагментованим животињским костима и, ретко, другим предметима какви су кремени одбици и метални артефакти. За сада у овом слоју нису пронађени остаци било каквих чврстих структура који би индиковали станишта или гробове, те се тренутно ништа прецизније не може рећи о карактеру локалитета. У западном делу Сонде 2018/III, на релативној дубини од око 1,9 м, пронађена је зона са групом керамичких уломака од неколико већих посуда који су се налазили in situ. Од ових фрагмената су свакако најиндикативнији остаци велике зделе увученог обода, украшеног канеловањем помоћу назубљеног инструмента (радлом) и утиснутим S-мотивама на ободу посуде и испод њега. У оквиру поменуте групе керамике (Т. 1/ 9, 10, 11) пронађен је, између осталог, и један медијални фрагмент кременог сечива (Т. 1/3). Ситни трагови гарежи, трагови горења на фрагментима керамике, камена и животињским костима који су били видљиви, ипак су недовољна индикација за хипотетичку девастацију праисторијске куће, нарочито јер ни подница ни трагови коља од зидова нису пронађени. Са поменутом групом керамике, судећи према фрагментима посуда који се спаjају, како је то касније установљено, стоји у вези и јама 1, откривена нешто јужније (сл. 1). Јама 1 је била кружне основе, укопана у кречњачку подлогу, горњег пречника 1,36 м, и сужавала се ка дну, релативне дубине 0,4 м. Током пражњења испуне ове јаме установљени су остаци кућног лепа, животињских костију и остаци већих посуда (лонаца, здела са посувраћеним ободом и других посуда) (Т. 1/1, 4, 7).

Недалеко од описане ситуације пронађена су још два укопа која потичу из овог периода. Јама 2, неправилне кружне основе пречника 1,35 м налазила се у крајњем северозападном делу сонде. Садржај ове јаме, поред фрагмената керамике старијег гвозденог доба, чинило је једно калотасто дугме од бронзаног лима и животињски астрагал (Cervus elaphus) са перфорацијом (Т. 1/6). Пронађено је такође дистално фрагментовано сечиво од кремена, билатерално 
ретуширано са суженом базом (Т. 1/2). Керамички материјал из ове јаме чине и фрагменти тракасте дршке са дугметастим протомом, те остаци посуде са заравњеним ободом и језичастом дршком (Т. $1 / 5,8)$. Судећи према инвентару испуне, укључујући и јаму 3 , која је залазила у северни профил сонде, реч је о укопима који су могли служити као отпадне јаме. Такву претпоставку потврђује и фрагмент каменог жрвња пронађен у јами 3.

Формалне аналогије керамичког материјала „Басараби стила” упућују на археолошке локалитете у непосредној близини, као што су Петрлашка пећина и Црноклиште (Kapuran et al. 2015, T. VIII, Пејић 2017, Т. 7, 8). Калотасто дугме од бронзаног лима, иако карактеристично, није довољно хронолошки осетљиво, будући да су бронзана дугмад познат репертоар хумки Централног Балкана од позног бронзаног па све до гвозденог доба (нпр. Madas 1996, Abb. 1.6; Popović i Vukmanović 1998, 20, Pl. 5. 20). У сваком случају, пронађен покретни материјал говори да би на подручју Источне некрополе Ремезијане требало рачунати на значајнији хоризонт старијег гвозденог доба, који, према прелиминарној анализи покретног археолошког материјала, можемо широко определити између 9. и 7. века п. н. е. Остаје тек да се утврди о каквој врсти локалитета се ради, мада читав слој и отпадне (?) јаме упућују на постојање насеља, које је, могуће, на вишим котама него истражени простор и чији су остаци приликом процеса спирања формирали праисторијски слој.

\section{Закључна разматрања}

Истраживања Источне некрополе 2018-2020. године прва су систематска истраживања на овом локалитету, што отвара бројне (претходно недоступне) могућности. Под овим подразумевамо да унапређени методолошки принципи прикупљања података приликом ископавања, као и антрополошке и физичко-хемијске анализе хуманог остеолошког материјала, уз побољшане теоријске оквире, могу да нам пруже драгоцене нове увиде о различитим аспектима живота у касноримском периоду. Најпре, детаљно евидентирање карактеристика гробних целина, од њихових просторних односа, преко врста конструкција, до гробног инвентара, у комбинацији са савременим методама физичко-антрополошке анализе, пружају могућност много бољег разумевања друштвених структура касноантичког урбаног друштва. Ако овоме додамо и планиране физичко-хемијске анализе остеолошког материјала, распон и разноврсност истраживачких питања и одговора могао би да достигне велике размере и квалитет. Наравно, све поменуте могућности непосредно проистичу из чињенице да је некропола, колико се 
за сада може закључити, врло вероватно веома добро очувана. Другим речима, захваљујући пракси покопавања покојника на релативно великим дубинама, може се очекивати да источно ремезијанско гробље има већи број непоремећених и неоштећених гробних целина из којих је могуће добити максимум релевантних података.

Додатно, систематска истраживања касноантичке Ремезијане, иако тек на почетку и, за сада, на малој површини, показују веома занимљиву разноликост гробних форми. Тако налази меморије и гробнице типа менса, „девијантне” сахране са ненормативним погребним ритуалом и једноставног гроба који је садржао скупоцене предмете (да поменемо само најупадљивије примере), упућују на много сложеније друштвене и ритуалне динамике него што се обично претпоставља за касноантичке некрополе. Поврх тога, важно је узети у обзир да је некропола хронолошки смештена у 4. век, који је сам по себи време турбулентних и преломних догађаја на пољима од политике, администрације и економије, до религије, миграција и културних трансформација. У том светлу, истраживање Источне некрополе Ремезијане, са свим својим разноврсностима и особеностима, омогућава преиспитивање да ли су се, у којој мери и на које начине сви поменути преображаји и динамике „преламали” у сфери погребних пракси и третмана умрлих (Janković 2021). Тачније, систематска истраживања и анализе података добијених са ове некрополе отварају пут ка дубљем разумевању и стварању сложеније представе о ремезијанском друштву, али и о ефектима ширих процеса који су обликовали касноримску епоху. Стога, није претерано очекивати да ремезијанско источно гробље одражава сву комплексност времена које се с правом сматра размеђем старог и средњег века.

Још један значај систематских ископавања на простору Источне некрополе Ремезијане лежи у чињеници проналаска слоја из старијег гвозденог доба. Иако су за сада од археолошких структура пронађене само јаме, добри су изгледи да је читав слој исход разградње и ,развлачења” остатака насеља које се налазило у близини, али навише уз падину Великог курила. Уколико би се кроз наставак систематских ископавања касноантичке некрополе пронашла и истражила локација насеља, то би било изванредно значајно за познавање периода 9-7. века пре н. е., не само на подручју Белопаланачке котлине већ и у ширем ареалу Понишавља. Другим речима, истраживани локалитет код хотела „Есперанто” завређује истраживачку пажњу јер је двоструко значајан за унапређивање и проширивање археолошких знања о ЈИ Србији. 


\section{СКРАЋЕНИЦЕ}

RIC VIII - The Roman Imperial Coinage; Kent, J. P. C. 1981. The Roman Imperial Coinage. The Family of Constantine I, A. D. 337-364. Volume VIII. London: Spink and Son LTD.

\section{БИБЛИОГРАФИЈА}

Vasić, M. i Milošević, G. 2000. Mansio Idimum: Rimska poštanska i putna stanica kod Medveđe. Beograd: Arheološki institut i Narodni muzej.

Величковић, М. 1964. Надгробна статуа Амора из Губеревца. Зборник радова Народног музеја IV: 129-140.

Gábor, O. 2014. Early Christian Buildings in the Northern Cemetery of Sopianae. Studia Patristica LXXIII 39-58.

Гојгић, А. и Вујадиновић, В. 2019. Сондажна истраживања касноантичке меморије и некрополе у Пријевору 1977. године. Зборник радова Народног музеја (Чачак) XLIX: 7-24.

Göricke-Lukić, H. 2000. Sjeveroistočna nekropola rimske Murse. Zagreb-Osijek: HANU, Zavod za znavstveni i umjetnički rad Osijek, Muzej Slavonije Osijek.

Dautova Ruševljan, V. 2003. Kasnoantička nekropola kod Sviloša u Sremu. Novi Sad: Matica srpska.

Dautova Ruševljan, V. 2016. Rimski period u Hrtkovcima. Novi Sad: Pokrajinski zavod za zaštitu spomenika kulture.

Дрча, С. 2000. Римско стакло у Нишком музеју. Гласник српског археолошког друитва 15/16: 209-229.

Дрча, C. 2004. Naissus. Каталог, у: Археолошко благо Ниша од неолита до средњег века, ур. Д. Пешић, 49-58, 192. Београд: Српска академија наука и уметности.

Duplančić, A. 2017. Membra disiecta jednoga salonitanskog mauzoleja. Tusculum 10/1: 71-94.

Зотовић, Љ. и Јордовић, Ч. 1990. Viminacium 1: некропола „Више гробаља”. Београд: Археолошки институт и Републички завод за заштиту споменика културе.

Живић, М. 2003. Felix Romuliana: 50 година одгонетања. Зајечар: Народни музеј.

Janković, A. M. In press. Remesiana in the 4th century AD: Late Roman and/or Early Christian Site? In Archaeology of Crisis, Ed. S. Babić. Belgrade: Faculty of Philosophy.

Jeremić, G. 2009. Saldum. Roman and Early Byzantine Fortification. Belgrade: Institute of Archaeology.

Јеремић, Г. 2014. Јагодин мала. Касноантичка некропола. Ниш: Народни музеј.

Јованова, Л. 2015. Скупи - некрополи основни карактеристики, у Јованова, Л. Скупи - некрополи: Стории за истакнати личности според епиграфски и археолошки сведоштва, 9-44. Скопје: Каламус.

Jovanović, A. 1978. Nakit u rimskoj Dardaniji. Beograd: Savez arheoloških društava Jugoslavije. 
Каниц, Ф. 1985. Србија, земьва и становниттво: од римског доба до ХІХ века. Къига 1. Београд: Српска књижевна задруга.

Kapuran, A. Blagojević, M and Bizjak, D. 2015. Settlements and necropolises of the Early Iron Age along the middle course of the Nišava river. Cmapuнap LXV: 145-181.

Kent, J. P. C. 1981. The Roman Imperial Coinage. The Family of Constantine I, A.D. 337-364. Volume VIII. London: Spink and Son LTD.

Крунић, С. 2006. Каталог, у: Магија ћилибара, ур. А. Палавестра и В. Крстић, 373. Београд: Народни музеј.

Kurilić, A. and Serventi, Z. 2018. Late Roman Tombs and Burial Places in the Province of Dalmatia. In International Scientific Conference The Basilica of St. Sophia During The Transition From Paganism To Christianity Sofia, March 11-13, 2014, 450-468. Sofia: Faber. Madas, D. 1996. Resultaten der Forschungen an Tumuli der späten Bronzezeit auf der Lokalität Paulje bei Loznica, u Jugoslovensko Podunavlje i susedne oblasti u II milenijumu p. n. e., ur. N. Tasić, 227-230. Beograd-Vršac: SANU.

Marijanski-Milošević, M. 1987. Rimska nekropola kod Beške u Sremu. Novi Sad: Vojvođanski muzej.

Milovanović, B. 2018. Jewelry as a Symbol of Prestige, Luxury and Power of the Viminacium Population. In Vivere Militare Est. From Populus to Emperors - Living on the Frontier. Volume II, ed. M. Korać, 101-142. Belgrade: Institute of Archaeology.

Milošević, G. 2005. Funerary structures on private estates in the later Roman Empire: case study Viminacium, in Römische Städte und Festungen and der Donau, Akten der regionalen Koferenz, Beograd 16-19 Oktober 2003, Hrsg. M. Mirković, 177-184. Beograd: Filozofski fakultet.

Milošević-Jevtić, G. 2014. Architecture of 'the family mausoleums' on Danube limes between Singidunum and Pontes, in International Multidisciplinary Scientific Conference on Social Sciences and Arts SGEM2014, Conference Proceedings, September 1-9, 2014, Book 3, Vol. 1, 323-330. Wien: SGEM World Science.

Милошевић, П. 2001. Археологија и историја Сирмијума. Нови Сад: Матица српска. Пејић, П. 2015. Античка топографија пиротског краја, докторска дисертација, Универзитет у Београду.

Пејић, П. 2017. Локалитет чесма - Горње поље у селу Црноклишту, у: Археолошка истраживања на аутопуту E80, ур. И. Продановић Ранковић, 349-378. Београд: Републички завод за заштиту споменика културе.

Petković, S. 1995. Rimski predmeti od kosti i roga sa teritorije Gornje Mezije. Beograd: Arheološki institut.

Petković, S. 2010. Rimske fibule u Srbiji od I do Vveka n. e. Beograd: Arheološki institut. Petković, S. 2011a. Crossbow fibulae from Gamzigrad (Romuliana). Starinar LX: 111-136. Petković, S. 2011b. Romuliana in the time after the palace. In Felix Romuliana - Gamzigrad, ed. I. Popović, 167-200. Belgrade: Institute of Archaeology and Institute for Theological Research.

Petković, S., Ružić, M., Jovanović, S., Vuksan, M. and Zoffmann. K. Zs. 2005. Roman and Medieval Necropolis in Ravna near Knjaževac. Belgrade: Archaeological institute. 
Петровић, Б. 1997. Накит, у: Античка бронза Сингидунума, ур. С. Крунић, 83-157. Београд: Музеј града Београда.

Петровић, Ј. Б. 1998. Природа Беле Паланке и средњег Понишавља. Нови Сад: Универзитет у Новом Саду, Природно-математички факултет, Институт за географију.

Петровић, П. и Јовановић, С. 1997. Културно благо књажевачког краја: археологија. Београд: Археолошки институт.

Поповић, И. 1994. Каталог, у: Античко сребро у Србији, ур. И. Поповић, 308, 336. Београд: Народни музеј.

Поповић, И. 2001. Касноантички и рановизантијски накит од злата у Народном музеју у Београду, Антика 8. Београд: Народни музеј = Popović, I. 2001. Late Roman and Early Byzantine Gold Jewelry in National Museum in Belgrade, Antiquity 8. Belgrade: National Museum.

Popović, P. i Vukmanović, M. 1998. Vajuga-Pesak, Nekropola starijeg gvozdenog doba, Đerdapske sveske, Posebna izdanja 3. Beograd: Arheološki institut i Narodni muzej.

Raičković, A. i Milovanović, B. 2009. Rezultati istraživanja jugozapadnog dela lokaliteta Pirivoj (Viminacijum). Arheologija i prirodne nauke 5: 7-56.

Ratković, D. 2013. Nakit, u: Pokloni Sofije i Milojka Dunjića, ur. T. Cvjetićanin, 129150. Beograd: Narodni muzej.

Решић, С. 2013. Римске појасне гарнитуре на тлу Србије од I до IV века. Докторска дисертација, Универзитет у Београду.

Ružić, M. 1994. Rimsko staklo u Srbiji. Beograd: Centar za arheološka istraživanja.

Ружић, М. 2017. Локалитет Гладно поље код Беле Паланке (Remesiana), y: Археолошка истраживања на аутопуту E80, ур. И. Продановић-Ранковић, 209-254. Београд: Републички завод за заштиту споменика културе.

Ружић, М. и Лазић, М. 2015. Резултати археолошких истраживања на територији општине Бела Паланка у периоду од 2002. до 2104. године. Белопаланачки зборник 8/9: 7-30.

Сабовљевић, Д. 1887. Дописи. Старинар IV: 91-99.

Симић, 3., Јанковић, М. А., Михајловић, В. Д. 2012. Касноантичка некропола у селу Ушћу код Обреновца. Гласник Српског археолошког друштва 28: 179-200.

Стаменковић, С. Иванишевић, В. и Пешић, J. 2016. Римска некропола у Малој Копашници, у: Археолошка истраживања на аутопуту E75 (2011-2014), ур. С. Перић и А. Булатовић, 17-45. Београд: Археолошки институт.

Фидановски, С. 1998. Каталог, у: Археолошко благо Косова и Метохије од неолита до раног средњег века. Каталог, ур. Д. Срејовић, 280, 294. Београд: Српска академија наука и уметности.

Цермановић-Кузмановић, А., Велимировић-Жижић, О. и Срејовић, Д. 1975. Античка Дукља: некрополе. Цетиње: Обод.

Цвјетићанин, Т. 2006. Касноантичка глеђосана керамика. Глеђосана керамика Прве Мезије, Приобалне Дакије, Средоземне Дакије и Дарданије. Београд: Народни музеј. Цвјетићанин, Т. 2016. Касноримска керамика Бердапа. Београд: Народни музеј. 


\title{
Marko A. Janković
}

The Archaeological Collection, Faculty of Philosophy, University of Belgrade

\section{Vladimir D. Mihajlović}

Department of History, Faculty of Philosophy, University of Novi Sad

\author{
Aleksandar D. Bandović
}

The National Museum, Belgrade

\section{THE PRELIMINARY RESULTS OF EXCAVATIONS OF THE EASTERN NECROPOLIS OF REMESIANA 2018-2020}

\author{
Keywords: Dacia Mediterranea, Remesiana, \\ necropolis, Late Roman period, Early Iron Age
}

The eastern necropolis of (Late) Roman Remesiana was known only by chance finds of graves up until recently. In 2018, systematic excavations began, conducted in three campaigns. The research pointed to the existence of burials from the second half of the $4^{\text {th }}$ century, which were part of the large necropolis on the northern slope of the Veliko Kurilo hill. During the three excavation seasons, a total of 29 funerary units were discovered, which were positioned in and around two burial objects and contained skeletal remains of 31 individuals (two of the graves were double interments). The first burial object, of the memoria type according to the traditional local terminology, had a square plan, was preserved only in its foundational zone, which was constructed of rough-cut stone without a binding material. There were two burial spaces inside the object: one (in the NW corner), which could be regarded as central (no. 16), was built of bricks and mortar, and contained burials of two individuals; another (no. 9) was also a double interment, but positioned immediately behind the entrance (at the eastern wall) in a simple rock-cut grave pit. The central burial contained a silver crossbow brooch, silver coin (Constantius II), two glass vessels and shoe-nails. It was most probably used in the second half of the $4^{\text {th }}$ century and was demolished at the end of the $4^{\text {th }}$ and beginning of the $5^{\text {th }}$ century.

The second object was constructed in a similar manner, but it was of a different type: its base was in the form of a horseshoe, with an apsidal ending in the western part, where an entrance was also positioned. Inside the object, next to its eastern wall, there was a platform built of pebbles and rough-cut stone (dim. $1.6 \times 1.2 \mathrm{~m}$ ) and topped with mortar, also in the shape of a horseshoe. This indicates that the burial structure was of a rare type, with the platform that served as a 
base for a "sigma" table used for funerary commensality practices. The funerary structure had a grave (no. 24) inside its perimeters, built of bricks and mortar, that contained the remains of one individual buried with a bronze crossbow brooch, belt buckle and glass vessel. Similarly to the previously discussed object, this one was also used during the second half of the $4^{\text {th }}$ century and was devastated in the end of the $4^{\text {th }}$ or the beginning of the $5^{\text {th }}$ century.

Other excavated graves were of well-known and common types: in nine of them, bricks were used for the construction (nos. 1, 2, 8, 11, 14, 17, 20, 21, 28), whereas the remaining 15 were burials in simple pits (nos. 3, 5, 7, 10, 12, 13, 15, $18,19,22,23,25,26,27,29)$. Bricks without binding material were usually used for construction of grave covers, in the form of a gable or laid horizontally in a row. Lower parts of simple pits were cut in the limestone bedrock, and their bottom was framed with a row of stones only rarely. Nearly all of the graves had the same orientation (W-E), and save for several cases, no burial markers survived, nor the original upper levels of graves could be discerned. Only one of these graves showed exceptional features (no. 3) as it was a "deviant" burial of a person facing downwards, followed by practices that left burned and broken pottery and metal objects, and animal bones.

The objects found inside the burials mostly belong to the common sorts and types of Late Roman funerary assemblages: jewellery (glass beads for necklaces, bronze, iron and bone bracelets, earrings, finger-rings) and accessories (crossbow brooches, belt and strap buckles). Somewhat rarer finds are (completely or mostly) preserved ceramic and glass vessels, while exceptional ones are represented by golden earrings, silver crossbow brooch, silver coin and iron stylus.

The Late Roman graves were dug in through the prehistoric layer that was formed out of remains belonging to the Early Iron Age. No habitation or burial structures from this period were found, but this layer and three discovered pits abounded with various potsherds and fragmented animal bones. Besides these, several flints and few metal objects were found as well. According to the stylistic features of pottery (i.e. the "Basarabi style"), the layer is dated into the $9^{\text {th }}-7^{\text {th }}$ century BCE and perhaps indicates the remains of a settlement further uphill. 

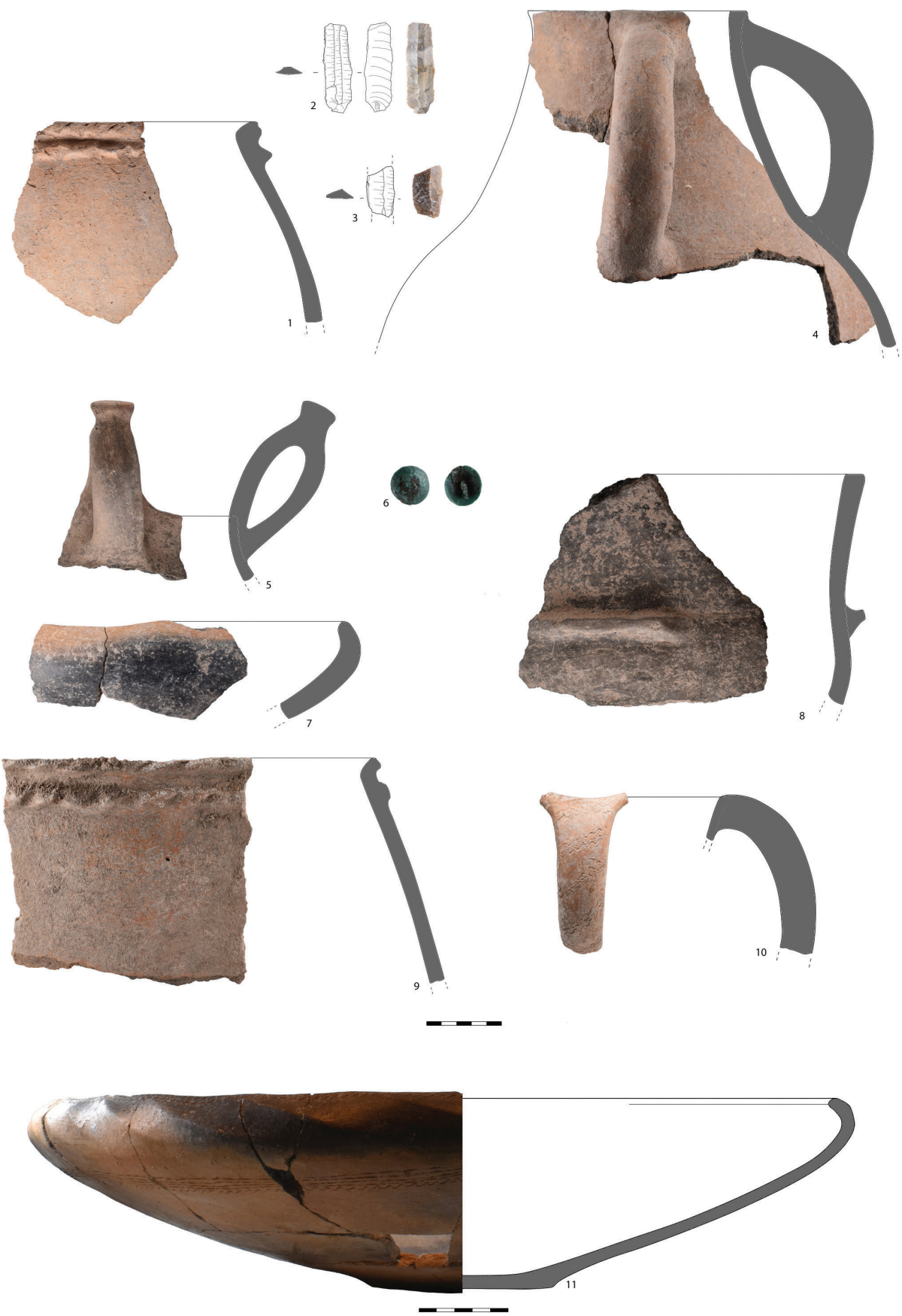

T. I Предмети откривени у гвозденодопском слоју

PI. I Objects from the Iron Age horizon 